PHOSPHORUS NUTRITION OF SOYBEANS AS AFFECTED

BY PLACENENT OF FERTILIZER FHOSPHORUS

A Thesis

Presented to

The Faculty of Graduate Studies and Research

University of Manitoba

In Partial Fulfillment

of the Requirements for the Degree

MASTER OF SCIENCE

by

Courtney W. Bullen

October, 1980 


\section{PHOSPHORUS NUTRITION OF SOYBEANS AS AFFECTED \\ BY PLACEMENT OF FERTILIZER PHOSPHORUS}

\section{BY}

Courtney Walton Bullen

A thesis submitted to the Faculty of Graduate Studies of the University of Manitoba in partial fulfillment of the requirements of the degree of

\section{MASTER OF SCIENCE}

(c) 1980

Permission has been granted to the LIBRARY OF THE UNIVERSITY OF MANITOBA to lend or sell copies of this thesis, to the NATIONAL LIBRARY OF CANADA to microfilm this thesis and to lend or sell copies of the film, and UNIVERSITY MICROFILMS to publish an abstract of this thesis.

The author reserves other publication rights, and neither the thesis nor extensive extracts from it may be printed or otherwise reproduced without the author's written permission. 


\section{ACKNONI IDG INENTS}

The writer wishes to express his appreciation to:-

Dr. R.J. Soper, Professor, Department of Soil Science, under whose immediate supervision this study was carried out, For his helpful advice and constructive criticism during the preparation of the manuscript;

Dr. G.J. Racz and Dr. W. Woodbury for serving on the committee;

Dr. I.D. Bailey who kindly consented to the use of facilities and data from the Brandon Research Station;

Dr. and Mrs. R.A. Hedlin who made every effort to ensure that my vife and I enjoyed our stay in Canada;

The Canadian Commonwealth Scholarship and Fellowship Committee for providing funds during the course of studies; My Vife and Son who provided an invaluable source of inspiration and encouragement and to whom this work is dedicated. 
ABSTRACT

Growth chamber and field experiments were conducted on Southern Manitoba soils varying in soil available phosphorus, to investigate the effects of various placement methods and levels of phosphorus fertilizer application, on soybean (Glycine Max (I.) Merrill, cultivar Maple Presto).

It was found that soybean responded well to applied phosphorus on low-P soil ( $4.6 \mathrm{ppm} \mathrm{P} \mathrm{NaHCO}_{3}$ extractable) in growth chamber studies. In the first of two growth chamber experiments, $0.1,0.2$ and $0.4 \mathrm{gm} \mathrm{P}$ (a.s Ca $\left(\mathrm{H}_{2} \mathrm{PO}_{4}\right)_{2} \cdot 2 \mathrm{H}_{2} \mathrm{O}$ ) were applied to 100\%, 50\%, 25\%, $12.5 \%$ and $1 \%$ of the total soil volume. Dry matter yields, total phosphorus uptake and utilization of fertilizer phosphorus increased at each level of applied $P$, as the size of the phosphated band was decreased. The results were attributed partly to greater chemical availability of $P$ in the smaller zones of $P$ fertilizer reaction. "A" values in this study increased with the amount of $p$ added. It was concluded that the potentially available soil phosphorus increased as the plant roots, enhanced by P fertilization, extended to explore the reservoir of soil phosphorus.

In the second growth chamber experiment, soybean responded differently to phosphorus banded in six different locations below the seed at $0.2 \mathrm{gm}$ and $0.4 \mathrm{gm} \mathrm{P} / \mathrm{pot}$. Placement of the fertilizer $2.5 \mathrm{~cm}$ directly below the seed was more effective in increasing dry matter yield, total phosphorus uptake and 
fertilizer $P$ utilization than placement $2.5 \mathrm{~cm}$ and $5 \mathrm{~cm}$ away at the same depth or placement $5 \mathrm{~cm}$ below the seed, whether the band was directly below, $2.5 \mathrm{~cm}$ away or $5 \mathrm{~cm}$ away. Dry matter yields and total $P$ uptake with $P$ banded $2.5 \mathrm{~cm}$ directly below the seed, compared favourably with yields and total $P$ uptake achieved by treating $1 \%$ of the soil volume with similar levels of $P$. However, the former placement method resulted in significantly better fertilizer P utilization.

Soybean yield responses in the first field study were greatest with $P$ banded $2.5 \mathrm{~cm}$ directly below the seed on low$P$ soils ( 4.8 and $4.3 \mathrm{~kg} \mathrm{P} \mathrm{P}_{2} / \mathrm{ha}-\mathrm{NaHCO}_{3}$ extractable). P was applied as $0-46$ - 0 at $20,30,60$ and $120 \mathrm{~kg} \mathrm{P}_{2} \mathrm{O}_{5} /$ ha at the two sites. No significant yield increases were obtained when the application rate was increased from 60 to $120 \mathrm{~kg} \mathrm{P}_{2} \mathrm{O}_{5}$ / ha and in some cases grain and dry matter yields were reduced. Placement of $\mathrm{P} 2.5 \mathrm{~cm}$ below the seed at $60 \mathrm{~kg} \mathrm{P} \mathrm{P}_{2} \mathrm{O}_{5} /$ ha resulted in grain yields that were $64 \%$ and $50 \%$ higher (at the two sites) than those obtained in control plots. Sidebanding $P$ at 2.5 $\mathrm{cm}$ below and $2.5 \mathrm{~cm}$ away from the seed at the same level of application, improved grain yields of control plots by $40 \%$ and 39\%. Seed placement and broadcast applications of $\mathrm{P}$ were not as effective in increasing grain yields. Broadcasting $P$ in Spring or in Fall at rates of up to $120 \mathrm{k}_{8} \mathrm{P}_{2} \mathrm{O}_{5} / \mathrm{ha}$ did not result in significantly higher grain yields than those obtained in control plots. Placement of $\mathrm{P}$ in contact with the seed 
appeared to reduce seedling emergence, resulting in depressed grain yields when $120 \mathrm{~kg} \mathrm{\textrm {P } _ { 2 }} \mathrm{O}_{5}$ / ha was applied.

In another field study where soils had test levels of $17.15,27.69$ and $29.66 \mathrm{~kg} \mathrm{P}_{2} \mathrm{O}_{5} / \mathrm{ha}\left(\mathrm{NaHCO}_{3}\right.$ extractable), no significant yield responses were obtained from soybean when $P$ was applied at 30 and $100 \mathrm{~kg} \mathrm{P}_{2} \mathrm{O}_{5} / \mathrm{ha}$. Phosphorus was banded $5 \mathrm{~cm}$ below and $5 \mathrm{~cm}$ away from the seed. 
TABLE OF CONTENTS

CHAPTER

PAGE

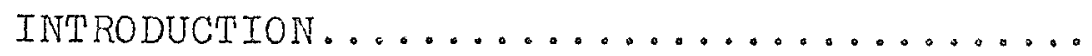

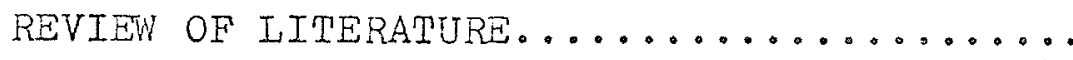

A. The Role of Phosphorus in Soybean...

B. Phosphorus Uptake Mechanism........

C. Some Factors Affecting Soybean

Response to Added Phosphorus........

D. Yield and Chemical Composition of Soybeans: Effect of P........... 30

III MATERIALS AND METHODS.............. 37

A. Growth Chamber Experiments........ 37

1. First Growth Chamber Experiment 37

2. Second Growth Chamber Experiment 41

B. Field Experiments............ 42

1. Phosphorus Placement study..... 43

2. Rate Study.............. 4 ?

C. Analytical Procedures............ 49

IV RESULTS AND DISCUSSION............. 52

A. First Growth Chamber Experiment.... 52

B. Second Growth Chamber Experiment... 72

C. Field Experiments............. 8 ?

1. Phosphorus Placement Study..... 87

2. Rate study................. 103

V SUMMARY AND CONCLUSIONS $\ldots \ldots \ldots \ldots \ldots \ldots \ldots$

VI $\quad$ BIBLIOGRAPHY $\ldots \ldots \ldots \ldots \ldots \ldots \ldots \ldots \ldots \ldots$ 


\section{LIST OF TABLES}

TABIE

PAGE

1. Characteristics of Soil used in Growth

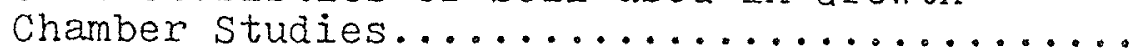

38

2. Treatment structure of Phosphorus

Application: First Growth Chamber

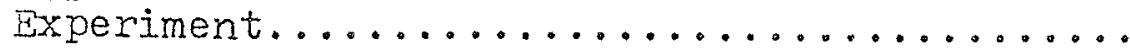

39

3. Characteristics of Soils used in Phosphorus

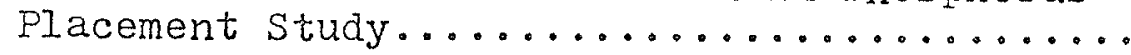

44

4. Monthly Rainfall at the two sites used in

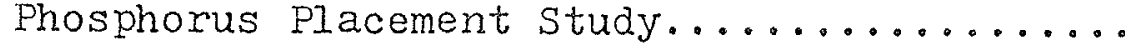

44

5. Sampling and Harvesting Dates for Phosphorus

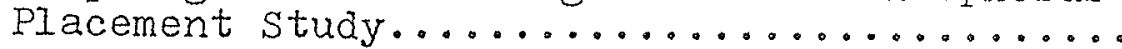

6. Characteristics of soils used in Rate study...

7. Dry Matter Yields of Soybean plants as affected by Rate of Phosphorus Fertilizer

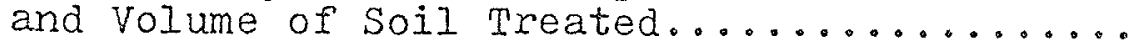

8. Total Phosphorus Uptake by Soybean Plants as affected by Rate of Phosphorus Fertilization and Volume of Soil Treated.............. 5 ?

9. Effect of Rate of Phosphorus Fertilization and Volume of Soil Treated on Phosphorus Derived from Fertilizer by Soybean Plants....

10. Efficiency of Utilization of Fertilizer Phosphorus as affected by Rate of Phosphorus Fertilization and Volume of Soil Treated....

11. Effect of Rate of Phosphorus Fertilization and Volume of Soil Treated on Phosphorus Derived from Soil by Soybean Plants.........

12. Change in "A" Values with changes in Amount of $P$ added and Volume of Soil Phosphorus.....

13. Percent phosphorus in Soybean Plant Tissues as affected by Rate of Phosphorus Fertilization

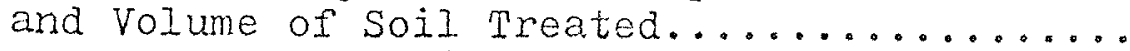




\section{LIST OF TABLES CONPINUED}

PABLE

PAGE

14. Dry Matter Yields of 44-day old Soybean plants as affected by Rate and Placement of Phosphorus

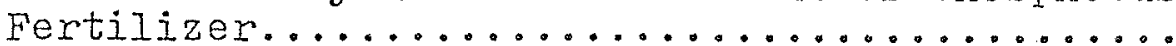

15. Total Phosphoms Uptake by 44-day old Soybean plants as affected by Rate and Placement of

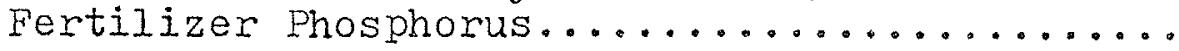

16. Effect of Rate and Placement of Fertilizer on Phosphorus derived from Fertilizer by $44-d a y$

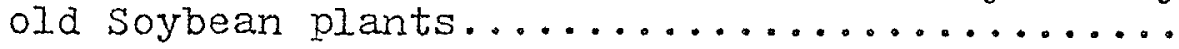

17. Percentage Utilization of Fertilizer Phosphorus by 44-day old Soybean plants as affected by Rate and Placement of Fertilizer Phosphorus....

18. Effect of Rate and Placement of Fertilizer Phosphorus on Phosphorus derived from Soil by 44 -day old Soybean plants...............

19. Percent Phosphorus in Plant Tissue of 44-day old Soybean plants as affected by Rate and Placement of Fertilizer Phosphorus...........

20. Dry Matter Yields of Field Grown Soybeans, at three growth stages, as affected by Rate and Placement of Phosphorus Fertilizer: Brandon

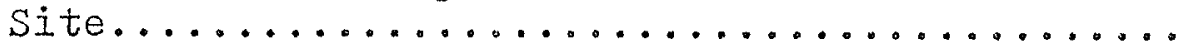

21. Dry Matter Yields of Field Grown Soybeans, at three Growth stages, as affected by Rate and Placement of Phosphorus Fertilizer: Neepawa.

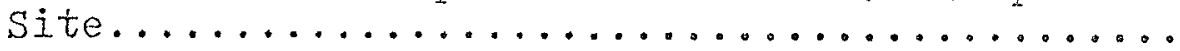

22. Grain Yields of Field Grown Soybeans as affected. by Rate and Placement of Phosphorus Fertilizer..

23. Total hosphorus Uptake by Field Grown soybeans at three growth stages, as affected by Rate and Placement of Phsophorus Fertilizer: Brandon

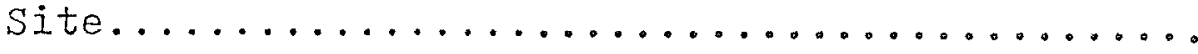

24. Total Phosphorus Uptake by Field Grown Soybeans at three Growth Stages, as affected by Rate and Placement of Phosphorus Fertilizer: Neepawa

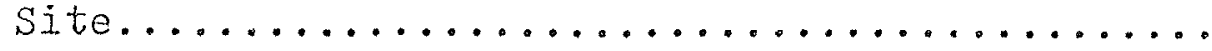


25. Total Phosphorus in Soybean Grain as affected by Rate and Placement of Phosphorus Ferti-

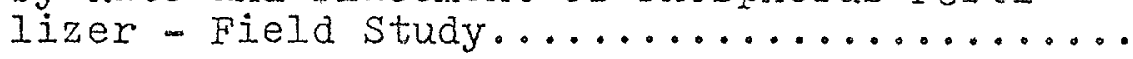

26. Percentage $P$ in Soybean Grain as affected by Rate and Placement of Phosphorus Fertilizer -

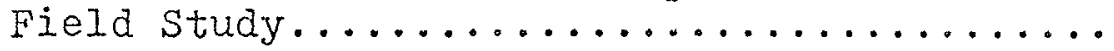

27. Influence of Rate and Placement of Phosphorus Fertilizer on Protein Content of Field Grown

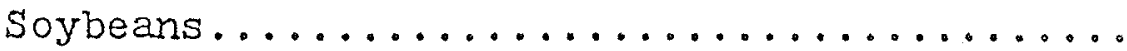

28. Grain Yields of Soybeans grown at three Southem Manitoba sites, as affected by Rate of Phosphorus Fertilization.............. 
1. Pattern of Dry Matter Production by Soybean plants as affected by amount of Phosphorus Added and volume of Soil Treated...........

2. Pattern of $P$ uptake by soybean plantis as influenced by amount of Phosphorus aôded and Volume of Soil Treated.............. 58

3. Graph of $\% \mathrm{P}$ Remaining in Solution vs $\mathrm{P}$ added for Soil used in Growth Chamber

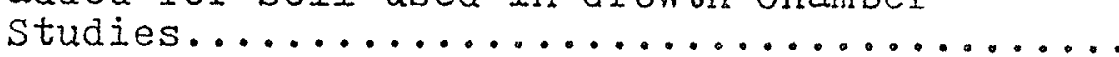

4. Relationship between Plant Dry Weight and Soil $P$ absorption in First Growth Chamber

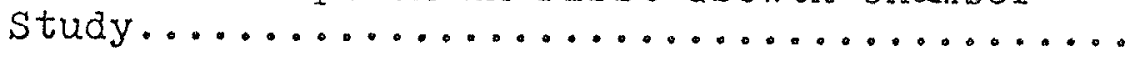


CHAPTER I

\section{INTRODUCTION}

Soybean (Glycine max (I) Merrill) is considered one of the world"s most important sources of vegetable oil and protein. The crop is relatively new to Western Canadian agriculture, when compared to other grain crops grown here. It was first introduced in Western Canada as a forage crop but it is now grown mainly as an oil-protein seed crop. Soybean seed is processed for edible oil, feed containing 44 to $50 \%$ protein is made from the remaining meal (Buzzell et al 1972). The rise in importance of the crop in Canadian agriculture is reflected in an increase in acreage planted, from 36,000 in 1944 to 295,000 in 1968. While the majority of the current acreage is cultivated in ontario, the crop is becoming increasingly popular with farmers in Manitoba and other Western Canadian provinces.

Research in several fields has contributed to the increase in soybean acreage and yield, world-wide. Plant breeders have been continually working on improving yield, maturity and adaptability of varieties. The Maple Presto variety was developed as an early maturing variety, adaptable to the relatively cool elimates of the southern Canadian prairies. Research in the area of soil fertility has met with mixed results. Numerous efforts have been devoted to investigating responses to Nitrogen fertilization and yield increases have been reported from 
nitrogen applications to nodulating soybeans (demooy et al 1973). Responses to phosphorus fertilization have however, been less favourable.

Phosphorus is an essential element for plant growth. Without an adequate supply of phosphorus a plant cannot attain its maximum growth potential, nor can it complete its normal reproductive processes. Most Canadian soils are deficient in phosphorus for optimum crop production and hence require the addition of fertilizer phosphorus. However, soybeans have been considered relatively unresponsive to phosphatic fertilizers when applied in the conventional methods. Once the need for fertilizer has been established, the following considerations should be made, (1) selection of the right form of fertilizer to ensure a high concentration of soluble and plant available compounds in the vicinity of the plant roots, (2) application of the fertilizer at the required time and in the required concentration to reduce losses due to soilfertilizer interactions. (3) placement of the fertilizer where it can be most efficiently utilized by the plant. The latter consideration is all the more important in the case of phosphorus which is relatively immobile in soil and is readily fixed by a number of soil constituents.

This study was undertaken to determine some of the conditions under which, soybean (Maple Presto variety) would respond to phosphorus fertilization. Attention was paid 
mainly to (a) phosphorus uptake by soybeans with phosphorus fertilizer applied in varying amounts to differently sized bands of soil, (b) the use and effectiveness of various methods of placement for $P$ fertilizers and (c) the use of various levels of $P$ application on soils varying in soil available P. 


\section{CHAFTER II}

\section{REVIEW OF IITERATURE}

\section{A. THE ROLE OF PHOSPHORUS IN SOYBEAN}

Phosphorus has a unique role in the metabolic processes of plants. It is essential for energy transfer in the living cell by means of the high-energy phosphate bond of adenosine triphosphate (ATP). This bond drives the mechanism for synthesis of cellular constituents. Phosphorus is therefore of prime importance in the formation and translocation of carbohydrates, fatty acids, glycerides and essential intermediate products (demooy et al, 1973). The element also enters the composition of nucleo-proteins which are basic components of the cell nucleus and of phosphatides that occur in soybean seeds. Phytin, a form of organic phosphate serves as a storage form of phosphate in seeds and on germination, phosphorus from this acid, or its salts becomes available for the phosphorylation reactions in the metabolism of the seedling (Arnon, 1953). Other phosphorus compounds also play critical roles in plant metabolism. Among these are the phosphate esters, phospholipids and the nucleic acids. Ribonucleic acid (PNA), for example, plays an important role in cell division, cell-wall differentiation, tissue differentiation and protein synthesis (Lee et al, 1966).

The effect of high-phosphorus treatments on the content 
of RNA, DNA and other phosphorus fractions in the early stages of soybean growth was examined by Lee et al (1966). Using two varieties which had previously been found to respond differently to high levels of phosphorus, the researchers observed changes in total phosphorus, RNA, DNA and other phosphorus fractions, when plants were grown in nutrient solutions ranging from 0 up to $18 \mathrm{ppm} P$. Of the two varieties, the sensitive Iincoln variety has been known to respond poorly to high-phosphorus treatments while chief is unaffected by similar treatments. It was found that total phosphorus content in the roots increased at a greater rate in the Iincoln variety than in Chief, at lower $P$ concentrations. Iincoln also accumulated acid-soluble $P$, phospholipids and RNA at a greater rate between 0 and 6 ppm $P$. However, at 18 ppm $P$, there was a decrease in all three fractions in Iincoln while Chief continued to accumulate phosphorus. Dry weight of Iincoln plants were also reduced with high phosphoms supply while yield of Chief was unaffected. The observed susceptibility of Lincoln variety, expressed in a yield reduction at high levels of $P$, was attributed to the decrease in RNA content of the leaf tissues.

Lee et al (I976) also observed increases in phosphatide $P$ up to a concentration of $3.0 \mathrm{mg} P /$ litre in nutrient solution, for sensitive varieties and up to $4.0 \mathrm{mg} P /$ litre for tolerant varieties. Such increases, it was thought, reflected an 
increase in the amount of intraculiular membranes and indicated cell enlargement. When RNA - P was expressed as a ratio with total $N$ content, the sensitive varieties again showed decreases at high $P$ concentration, while the tolerant varieties again showed slight increases. The results indicated that the tolerant varieties increased their rate of protein synthesis at high levels of $P$ in solution while sensitive varieties reached a maximum rate at a lower $P$ concentration. However, sensitive varieties seemed capable of accumulating a greater amount of total $F$ and this, together with a higher rate of protein synthesis, resulted in greater yields (of plant tops) at concentrations up to $3.0 \mathrm{mg}$ P/Iitre.

Nodulation responses of soybean to added phosphorus, potassium and calcium salts were investigated by dellooy and Pesek (1966). Five plant introductions were used in outdoor pot experiments in which $P, K$ and $C a$ applications were varied simultaneously, to determine theix individual as well as joint effects on nodulation. The findings confirmed that phosphorus fertility played a dominant role in optimising nodulation in soybean. Jarge and highly significant curvilinear responses in number, weight and leghaemoglobin content of nodules to $P$ application, were observed. The study also indicated that maximum nodulation and nodule activity required very high levels of applied $P$ and $K$.

Gates and Muller (1979) examined nodulation responses 
of soybean to nitrogen, phosphorus and sulphur at three growth stages: flowering, pod-fill and seed maturity. Working on a nutrient deficient soil, they again established the importance of phosphorus in nodulation but also found main effects for the other two elements. Interactions changed from nil at flowering to a fer $P \times N$ and $P \times S$ at pod fill and then to predominant $P x$ is at maturity. The investigation showed that nodulation was extremely sensitive to levels of nutrient combination with the best nodulation being obtained at high levels of all three elements. The phosphorus effect was earlier described by deMooy and Pesek (1973) as being two-fold; a smaller direct effect on the host plant tissues and a larger indirect effect, related to the extremely high requirements of nodule bacteria. Alexander (1977), in reviewing symbiotic nitrogen fixation in legumes, expressed the opinion that responses of the $\mathrm{N}_{2}$-fixing and nodulation mechanisms to phosphate fertilization are associated with the vigour and well-being of the host plant rather than reflections of a specific stimulation of symbiosis per se. 


\section{B. PHOSPHORUS UPTAKE MECHANISM}

Bray (1954) stated that the value of a soil nutrient to plants depends on its accessibility to the root which is consequently related to the mobility of the nutrient in the soil. In introducing a concept of nutrient mobility in soilplant relationships, he explained that extremes of mobility of the available forms of soil nutrients give rise to two kinds of root sorption zones. One is the large volume of soil occupied by the major part of the root system and the other is a relatively thin layer adjacent to each root surface. Mobile nutrients such as nitrogen, are absorbed from the larger volume while the relatively immobile elements such as phosphorus are absorbed from the latter area. The "root surface sorption zone" as he termed it, represents only a small part of the soil, hence roots feed on only a fraction of the immobile nutrients present. Nye (1968) pointed out that the zone of nutrient disturbance around a single root for $P_{p}$ is small compared with the zone of disturbance for $K$ and $N$. He noted that when the zone of depletion is small, the cylinder of root hairs surrounding the root should play an important role in the supply of $\mathrm{P}$ to the plant.

The importance of root morphology in the phosphorus up. take mechanisms of plants was also stressed by Lewis and Quirk (1967). In a series of studies aimed at assessing the signi- 
ficance of diffusion as a mechanism of phosphate transport through soil to plant roots, phosphate depletion patterns around wheat roots at various growth periods were studied with the aid of autoradiography. For all levels of phosphate applied, the zone of depletion was similar in size, extending approximately $1 \mathrm{~mm}$ from the root surface. Root hairs subsequently removed, showed numerous hairs of similar lengths (1 $\mathrm{mm}$ ) suggesting that in the soil in question, root morphology influenced the size of the depletion zone more than diffusion rates. Strong and Soper (1974, I) assessed the influence of root development within the fertilizer reaction zone on the utilization of applied $P$, for flax, wheat, rape and buckwheat. Two systems of fertilization were used, each with a simulated fertilizer reaction zone containing $32_{\mathrm{P}}$ labelled DCPD. In one system the reaction zone was positioned at the centre of the soil mass while in the other. the zone was positioned so that the entire root mass passed through it. Recovery of $\mathrm{P}$ from these two systems indicated that the proportion of the root system which feeds within the zone of reaction, as well as the opportunity given it to feed, influenced the utilization of band-applied P. Root systems of the four crops showed the ability to proliferate within a small zone, rich in $\mathrm{P}$, in an otherwise P-deficient soil. Robertson et al (1966) quoted evidence to support the concept that nutrient uptake is a function of actively absorbing root 
surface, concentration of the nutrient at the interface and a plant status factor i.e. plant demand. The influence of area of roots in the fertilizer zone on phosphorus uptake was investigated using brace roots of maize. One or two brace roots were directed into soil containing 0.62 or 3.10 gm $P$ labelled with $32 \mathrm{P}$. $P$ uptake varied with the rate of fertilization and the number of brace roots fed.

Apart from root morphology, reaction zone $\mathrm{P}$ concentration and the supply of phosphorus in the soil also influenced the $P$ uptake capabilities of plants. Strong and Soper (1974, II) studied the effect of these two parameters on $P$ utilization from band or pellet-like applications of phosphate. Two experiments were carried out in which band or pellet-like applications of $P$ were simulated and $32_{P}$ - labelled calcium phosphate was mixed with or confined to a small portion of the soil mass. In one experiment, the fertilizer reaction zone contained one of three calcium phosphates with widely differing solubility products: hydroxyapatite, octocalcium phosphate and dicalcium phosphate dihydrate. In the other, the availability of $\mathrm{P}$ in soil extemal to the reaction zone was increased by the addition of calcium phosphate throughout. In the first experiment, there was a reduction in crop recovery of $P$ with decreasing solubility of the three compounds, clearly demonstrating that $P$ concentration within the reaction zone influenced the uptake capabilities of the plants (flax. 
wheat, rape and buckwheat). In the second experiment, the amount of $\mathrm{P}$ recovered from the reaction zone was drastically reduced due to increased availability of soil phosphorus. The study indicated an inverse relationship between the availability of soil $-P$ and the utilization of $P$ from $a$ band application. The authors noted that reaction zone $P$ concentration and soil $P$ availability appear to affect the utilization of applied $P$ by their control over the performance of roots within the fertilizer reaction zone.

Other factors also exert some influence on the uptake mechanism for phosphorus in soybean. Edwards and Barbex (1976) considered that plant age played a role in the process. They measured the $P$ influx characteristics of intact soybean roots with plants ranging in age from 18 to 74 days. The rate of depletion from solution vs $P$ concentration in solution was used to determine maximum $P$ influx ( Imax), Michaelis constant $(\mathrm{Km})$, efflux $(E)$ and the lowest level to which plants can reduce $P$ concentration in solution (Cmin). Average Imax for $P$ was found to decrease with age while $\mathrm{Km}$ and $\mathrm{Cmin}$ both increased with age. When the results of this study were compared with results from a similar study on corn. it was found that soybean had lower Imax values at the seeding stage, but these values decreased with age at a lesser rate than for com. This was interpreted to mean that soybean seedings were cap able of extracting enough $P$ at lower levels of availability. 
The crop also seems capable of extracting $P$ at maximum rates for a longer period. These observations led the authors to conclude that this capability may be an underlying reason why soybean seedlings often do not respond to banding of $P$ fertilizer near the row. 
C. SOME FACTORS AFFECTING SOYBEAN

RESPONSE TO ADDED PHOSPHORUS

That crops differ in their abilities to extract both native and added phosphorus from soils has been established for some time and has already been alluded to in this review. As early as 1949. Krantz et al reported differential responses to added phosphorus by corn, cotton, soybean and potatoes. The utilization of soil and fertilizer phosphorus by these crops was compared using two levels of soil phosphorus and two rates of applied phosphorus (28 and $112 \mathrm{~kg} / \mathrm{ha} \quad \mathrm{P}_{2} \mathrm{O}_{5}$ ). Comparison of potatoes, com and soybean showed that potatoes absorbed the most fertilizer phosphorus and soybean the least. Corn, however, absorbed the greatest total amount of phosphorus and potatoes the least. In terms of yield, soybean did not show any significant response to added phosphorus on the high phosphorus soil ( $196 \mathrm{~kg} / \mathrm{ha} \mathrm{P}_{2} \mathrm{O}_{5}$ ). Although the crop appeared to derive a greater percentage of its $P$ supply from the fertilizer in the early growing stages, this decreased with age. Racz et al (1965) reported the results of a field study where wheat and rape gave differential yield responses to added $P$ fertilizer. Rape responded to a greater degree than did other crops, to added $P_{0}$, with the rate of absorption, measured over five growth stages, increasing in the order of flax, wheat and rape. This differential response was partly explained by the different rates of uptake and difference in total requirements of the plants for phosphorus. Webber (1963) 
also found, in green-house studies that the ratio of soil to fertilizer phosphorus in plants decreased in the order of flax, oats and rape. Kalra and Soper (1968) compared "A" values from a greenhouse experiment in which the efficiency of rape, oats, soybean and flax in absorbing soil and fertilizer phosphorus was assessed at seven growth stages. Soybean appeared to be much more efficient at extracting soil phosphorus whereas rape and oats which had consistently lower "A" values throughout the growth period appeared to be better at extracting fertilizer phosphorus. It was thought that these relative efficiencies were, in part, the reason why crops such as flax and soybean often failed to respond to phosphate fertilization.

Among varieties of soybean, important distinctions have been made with respect to their responses to high levels of phosphorus fertilization. Howell (1954) studied the response of several soybean varieties to different levels of $P$. Increasing the $P$ level from 2 to 10 ppm (nutrient solution) resulted in taller and heavier plants, greater seed yield and higher oil content for all varieties used. on a wider range of applied $P_{0}$. Chief variety continued to respond to levels as high as $112 \mathrm{ppm} P$ while Lincoln and Illini were adversely affected by levels of 50 and $112 \mathrm{ppm}$ P. Similar observations were made by Fletcher and Kurtz (1964) who found that Iincoln and Chief varieties responded similarly in terms of dry weight and mineral composition up to a rate of $974 \mathrm{~kg} / \mathrm{ha}$ of added $P$. 
Higher levels were better tolerated by Chief, while Iincoln exhibited marginal browning of the leaves, leaf drop and severe stunting at levels of $2934.4 \mathrm{~kg} / \mathrm{ha}$ of added $\mathrm{P}$. Howell and Bermard (1961) categorised 44 varieties of soybean according to their responses to high concentrations of phosphorus in nutrient solution. While the majority were classified as tolerant, the source of the sensitive response was traced to Lincoln variety which has been widely used as a parent in the development of a number of commercial varieties. It should be noted that varieties classified as very sensitive, occupied $24 \%$ of the commerical soybean acreage in the united States in 1959.

The utilization of applied phosphorus has been shown by a number of investigators, researching with soybeans, to be related to the level of soil phosphorus. Welch et al (1949) studied phosphorus utilization by soybean from soil and fertilizer using radioactive tracer techniques. They found that the percentage of phosphoms in the plant that was derived from the fertilizer was inversely related to the level of soil phosphorus. Similar observations were made by Bureau et al (1953) and Kamprath and Miller (1958). KaIra (1971) stated that this inverse relationship was true for several field crops. Crop response to added $P$ was found to be greatest when the ratio of $P$ derived from soil to $P$ derived from fertilizer was smallest. This observation mays in fact, account 
for a large number of cases where soybeans failed to respond to phosphate fertilization. Very little has been reported. however, on the actual levels of soil phosphorus below which responses to phosphate fertilization may be expected in soybeans. Chesney (1973) quoted United Nations Soil Survey of Guyana data which considered any soil with 20 ppm $P$ or less Truog-P to be of low $P$ status. Under the tropical conditions there, soybean responded to $\mathrm{P}$ applications of up to $58 \mathrm{~kg} / \mathrm{ha}$ in the first two years and up to $29 \mathrm{~kg} / \mathrm{ha}$ in the third year. It will be expected, however, that the conditions under which soybean will respond to phosphate fertilization will vary with the soil level of phosphate as well as with the variety used. Various researchers have estimated that soybeans require between 24 and $48 \mathrm{~kg} \mathrm{P} / \mathrm{ha}$ for optimum production.

Apart from the native phosphorus level in soil, responses to phosphorus fertilization by soybeans will also be conditioned by the concentration of $P$ in the zone of fertilizer activity (Kalra, 1971). Bureau et al (1953) used five sources of phosphorus, each labelled with radioactive $P$ to determine the effect of phosphatic fertilizer on uptake. Superphosphate and double superphosphate were about equally available as a source of phosphorus on high phosphorus soil while superphosphate was slightly superior on medium- and low- P soils. Calcium metaphosphate, while less available than the above two, in the early growing season, equalied superphosphate 
later in the season. It was, however, providing less phosphorus on the high-P soil over the entire growth period. Dicalcium phosphate was consistently inferior to calcium metaphosphate while fused tricalcium phosphate was the least available carrier used. With other crops, Strong and Soper (1974) demonstrated that reduction in solubility of phosphate compounds (DCPD, OCP, HA) decreased the uptake of phosphorus from band or pelletlike applications.

Many researchers have felt that soybeans do not respond to mineral fertilization per se but to the level of soil fertility. Boswell and Anderson (1975) conducted a three year study to determine if residual $N-P-K$ fertilizers applied over a period of years to non-leguminous crops would affect fertilizer requirements of soybean. The crop was grown on Rarden silt loam (Typic Dystrochrept) where plots had received the same rates of $P$ and $K$ for 13 years. Previous $N$ rates were 56 and $112 \mathrm{~kg} / \mathrm{ha}$ depending on the crop. Results showed that the highest rates of $\mathrm{N}-\mathrm{P}-\mathrm{K}$ produced significantly larger seeds, better seed quality and higher crude protein content, than low N-P-K rates or control plots. Phosphorus showed the greatest fertilizer $X$ year interaction effect on yield. However, al though relatively high rates of $P$ and $K$ were applied to some plots for 16 years previously, soil tests did not indicate high levels of extractable $P$ and $K$ in the soil. This soil has apparentiy fixed relatively large amounts of $P$ and $K$, and 
this could have partially accounted for the response to $P$ and $K$ applications. Thus the current fertilizer requirements of the crop had not been seriously affected by the previous fertilization history. dellooy et al (1973) compared the responses of corn and soybean to direct and residual $P$ and $K$ fertilization, on an energy basis, over four years of field experimentation. Corn proved to be significantly more responsive than soybean to both direct and residual $P$ fertilizer. Soybean showed little difference between the effect of direct and residual fertilizer on yield. It should be pointed out that this experiment was carried out on two sites and on the second site the level of available soil $P$ was raised to 26.9 $\mathrm{kg} \mathrm{P} / \mathrm{ha}$ (medium). Even though the response to $\mathrm{P}$ application was generally smaller at the second site, responses to residual fertility on the two sites were comparable.

Another factor which has been shown to affect phosphorus absorption by roots (and hence, response to added $P$ ) is the soil moisture tension. Olsen et al (1961) found that uptake of $P$ by com roots was a linear function of the soil moisture content for a given soil. The relative uptake of $P$ by corn seedlings was $100,94,80,50$ and 35 for $1 / 3, \frac{1}{2}, 1,3$ and 9 bars soil moisture tension respectively. The factors controlling uptake in relation to moisture tension included thickness of moisture films, diffusion path length, degree of hydration and elongation of roots. Uptake at a constant soil 
moisture tension on soils differing in texture and soluble $P$ level. was a linear function of soluble $P$. The authors also noted that soil introduces a limiting factor in rate of $P$ uptake since uptake from a soil-root system differed appreciably from a solution-root system.

Placement of phosphorus fertilizers appears to be a key element in illiciting responses to applied $P$ by various crops. Numerous recommendations have been made, regarding the place ment of $P$ fertilizers in relation to the seed for a number of row crops. However, it would appear that research of this nature, with respect to soybean, is lacking. Subsoiling and deep fertilization have been experimented with, in response to certain soil management difficulties arising from the presence of impermeable layers in some soils. Jamison and Thornton (1960) reported on such experiments on Mexico silt loam. They found that subsoil applications of lime and triple superphosphate placed in the subsoiler clefts or by deep ploughing, gave significant yield increases in corn and alfalfa. Phosphate applications to the plough sole before shattering was also slightly beneficial in the case of alfalfa. However, if the soil surface was adequately fertilized, the increases over surface treatment alone were small and of questionable value. Larson et al (1960) reported that subsoiling to depths of 16 and 24 inches in Iowa soils, together with fertilization at these depths was not as effective as fertilizer ploughed 
under, in the case of corn. Field experiments in Nebraska. and Illinois were carried out to compare chisel and mouldboard ploughing systems to ascertain the most effective method of $\mathrm{P}$ application in these systems (Cihacek et al, 1974). Mouldboard plough tillage following surface broadcast of $\mathrm{P}$ resulted in higher corn yields than chisel ploughing whether the fertilizer was broadcast, bancied or applied deep. However, chisel ploughing offered the benefits of moisture conservation and erosion control.

Camper and Lutz (1977) investigated the importance of a traffic pan (developed over years of tillage operations) in light textured Virginia soils. In an experiment conducted over a six-year period on Sassafras Sandy loam, comparisons were made of rates of $P, K$ and/or lime tilled and not tilled into the traffic pan after $15 \mathrm{~cm}$ of the surface soil had been removed. Tillage of the plough sole increased soybean plant height in one year, reduced it in two years, but over the six year period, average plant heights with or without tillage was indentical. Only in one out of six years did tillage increase yield. One of the reasons for conducting this study was the possibility that the traffic pan may have had the effect of reducing water infiltration and root penetration. Woodhouse (1956) had compared three placement methods for phosphate, potash and limestone on two legume-grass mixtures over a three-year period. While placement methods did not 
measurably affect the growth of lespedeza-dalizgrass mixture. surface placement of phosphate proved to be inferior to plough soil placement and mixing phosphate in the plough sole in an alfalfa-orchardgrass mixture. In contrast to this, Moore et al (1968) found that drilling $p$ fertilizer to a depth of 7.6 to $10.2 \mathrm{~cm}$ resulted in lower dry matter yields and lower percentages of phosphorus as compared with surface application on two Nebraska sub-irrigated meadows.

Greater success has generally been achieved when phosphorus was placed in the surface layers of soils at varying distances below and beside the seed. Sheard et al (1971) reported that results from a greenhouse and two field experiments using 32 p-labelled MCP. showed increased phosphorus uptake from fertilizer placed $5 \mathrm{~cm}$ directly below surface sown alfalfa seed or bromegrass. Dispersing $P$ throughout the soil volume, Iocalizing it on the soil surface or shifting the band laterally from the position below the seed, all decreased $P$ fertilizer uptake, resulting in decreased weight of individual seedlings of both plants. Banding of fertilizer for small grains is generally considered to be more efficient than broadcasting. Better positional availability of bands near or with the seed should encourage more rapid absorption of nutrients by young plants and elements such as phosphorus remain in a more available form over longer periods of time (Sherrell et aI. 1964). 
Detrimental effects have, however, been reported when relatively high rates of $N, P$ and $K$ have been placed in contact with seed for a number of row crops. Olson and Drier (1956) found appreciable seed damage to oats and wheat when $N$ in excess of $16.8 \mathrm{~kg} / \mathrm{ha}$ was applied in this manner, under especially dry conditions. Efficiency of applied $P$ was however, greater, when applied with the seed as against broadcasting before or after tillage, provided that accompanying $N$ did not exceed 11.2 to $16.8 \mathrm{~kg} / \mathrm{ha}$. Iutz et al (1961) found appreciable differences in the effectiveness of different placement methods for $\mathrm{P}$ with small grain forage in Georgia, Mississippi and Virginia. Broadcasting and discing in fertilizexs to supply $44.8 \mathrm{~kg} / \mathrm{ha} \mathrm{P}_{2} \mathrm{O}_{5}$ was $42 \%$ as effective and topdressing after emergence was 33\% as effective as application with the seed. With higher rates of $P$, however, placement in contact with the seed appeared to depress yields of wheat in comparison to placement away from the seed. Reduced and delayed seed emergence was reported by Bates (I97I, I) in several of 22 field trials in which fertilizer supplied to corn was banded with the seed at rates supplying $3.1,5.4$ and $2.5 \mathrm{gm} \mathrm{N}, P$ and $K$ respectively, per meter of row. This placement method however, increased, on the average, dry-weights of 36-day old plant by $36 \%$, decreased time to silking by 1.2 days, decreased ear moisture by $1.2 \%$ and increased grain yield by $2.9 \%$. Nybore and Henning (1969) reported no appreciable seed damage or delayed emergence at rates of $15-20 \mathrm{~kg} \mathrm{P} / \mathrm{ha}$ 
when commercial fertilizers were applied to barley, flax and rapeseed. Higher rates of fertilization produced greater yields when placement was away from the row, up to $2.5 \mathrm{~cm}$. Miller et al (1971) pointed out that the main advantage from fertilizer placed with the seed is the early growth response. High rates which delay emergence and cause seed damage would however, tend to cancel this advantage.

A number of other factors have been shown to influence the efficiency of fertilizer placed in close proximity to the seed. Terman et al (1961) reported increasing response to banded $P$ fertilizers by com, millet, oats and wheat, grown in greenhouse pots, with increase in the water soluble $\mathrm{P}$ content of applied $P$ fertilizers. These effects were much less for a second crop and there were no appreciable differences in a third crop (no additional fertilizers were used in the second and third crop). The authors also noted that yields were markedly reduced when pots were left for various periods (16. 24 and 32 days) in a water bath at $52-55^{\circ} \mathrm{F}\left(11.1-12.7^{\circ} \mathrm{C}\right)$. Response was greater to banded than to nixed phosphate applications both at normal greenhouse temperatures and in the water bath. Sherrell et al (1964) found that yield of oats was influenced by placement methods of phosphorus only on soils with an inherently low phosphorus level. While fertilizer $P$ absorption was greater from placement with the seed than from those to the side at all stages of growth, placement 
below the seed up to 2 inches, was superior to those with the seed in the early stages. At maturity, with-seed placement resulted in greater $\mathrm{P}$ absorption. It was generally felt that the effect of placement of phosphorus fertilizer for oats depended on the rate of application and the soil phosphorus level. Even so, placement with or directly below the seed proved superior to placement beside the seed. Bates (1971, II) used with-seed applications of $N, P$ and $K$ in combination with separate and larger amounts of $N, P$ and $K$ at various placements and with different amounts of pre-seeding tillage, in field experiments with corn. When no fertilizer was applied with the seed, side-banding $P$ resulted in slightly higher grain yields than where it was disced in or ploughed down. When accompanied by seed-placed fertilizer, $P$ was as effective ploughed down as it was sidebanded. Bates noted that application with the seed along with the main requirement being ploughed down, appeared to have practical advantages over sidebanding large amounts, under ontario conditions. In addition to giving higher yields, the former method required less time to fill hoppers and tanks during planting and also required less expensive fertilizer attachments.

Placement of phosphorus has proven to be of critical importance in crops that have been considered to be relatively unresponsive to $\mathrm{P}$ fertilizers. Field and greenhouse studies as well as farmer experience have shown that flax responds 
poorly to $P$ even when the fertilizer is placed with the seed on soils low in plant available P. Sadler (1979) studied the effect of different placements of $P$ banded away from the seed, on growth and uptake of soil and fertilizer p by flax. Previous studies by Bailey (1967) had indicated that flax responded significantly to phosphorus placed below the seed as opposed to sidebanding or broadcasting on a noncalcareous soil (Carroll clay loam). Sadlex's studies found that crop response was indeed, very sensitive to the location of applied P. Naximum yields and $P$ uptake which were 4 and 3.5 times, respectively. the $0 \mathrm{~kg} P / \mathrm{ha}$ treatment values, were achieved by placing the P fertilizer no more than $1.5 \mathrm{~cm}$ to the side and 1.5 to 3.0 $\mathrm{cm}$ below the seed. Root studies indicated that this was largely as a result of root development in the first few weeks being restricted to a small cylinder of soil immediately surrounding the vertical tap-root. Placement also appeared to be more critical on calcareous than on noncalcareous soils.

Information on phosphorus placement effects on soybean yield and phosphorus uptake is limited. Of the reports available on this subject, few point to significant responses by the crop to various $\mathrm{P}$ placement methods. Keogh and Maples (1970) reported on soybean fertilization studies including various rates, methods and times of application of phosphate and potash, carried out at four sites in Eastern Arkansas in 1967 and 1968. Broadcast and banded treatments were variously 
applied in late fall, early spring, late spring and at planting. While the crop yields showed responses to $44.8 \mathrm{~kg} \mathrm{P} / \mathrm{ha}$ treatments, there were no significant differences due to placement methods. At all sites, responses to phosphorus fertilization were negligible and whatever yield increases there were, were primarily attributed to potash fertilization. Ham et al (1973) used fertilizer treatments consisting of banded starter, starter in contact with seed, and a combination of banded and seed-placed fertilizer superimposed on broadcast treatments at three Minnesota Jocations. Environm mental factors such as rainfall, soil level of $P$ and soil temperature influenced the response. With low rainfall and low soil test level of $P$, broadcasting $P$ fertilizer gave the largest yield response. With adequate rainfall and low soil $P$, the largest response was to combinations of starter and broadcast treatments. In many instances, seed placement without broadcast and seed placement and/or band in combination with broadcast, decreased yields significantly. This was especially so on soils with a high level: of native phosphorus.

"Pop-up" fertilizers is the popular name given to fertilizers placed directly in the seed row. Usually. small amounts of fertilizers are placed in the seed row as a possible means of stimulating rapid seed germination and early seedling growth. Success and failures have been experienced with the use of this method on crops such as corn. Reduced stands and consequent 
yield reduction have been attributed to high rates of $N$ and $P$ applied in this manner. Clapp and Snall (1970) evaluated the use of small amounts of liquid and granular fertilizers applied directly in the soybean seed zone at planting. An application of 35.5 litres/ha of liquid $5.0-3.8-4.2(\mathbb{N}$. $P, K$ ) reduced stands by $57.8 \%$ and yields by $20.3 \%$. With the use of granular $10-15-5(N, P, K)$ reduction in stands were observed when the rate exceeded $11.2 \mathrm{~kg} / \mathrm{ha}$. Results of this study indicated that seed-placed fertilizer can be harmful to soybean stands and yields when certain rates are exceeded. However, the study did not single out any one element which may have been more or less injurious. Heoft et al (1975) conducted field trials on a loamy fine sand and a silt loam, using snapbeans and soybeans as test crops, to evaluate the effect of seed-placed fertilizer on emergence. Soybeans. planted on the silt loam soil were less sensitive to seed damage than snapbeans, which were planted on the loamy sand. The level of $\mathrm{N}$ was more important than $\mathrm{P}$ or $\mathrm{K}$ in statistically determining reduction in emexgence. Soybeans were able to tolerate up to $10.2 \mathrm{~kg} / \mathrm{ha}$ of seed-placed $\mathrm{P}$ without significant delay or reduction in emergence.

Although the benefits and/or dangers of phosphorus placement in close proximity to the seed, for soybean, appear to be shrouded in inconsistency, it has nevertheless, become common practice to apply at least part of the recommended fertilizers 
in this manner. This has become moreso, with the advent of high analysis fertilizers and higher rates of application. Ham and Caldwell (1978) attempted to determine the value of a number of placement methods that have been used in commercial production of soybeans and other crops. While $P$ application of $35 \mathrm{~kg} P / \mathrm{ha}$ on a low $\mathrm{P}$ soil ( $7.1 \mathrm{ppm} \mathrm{P}$ ) increased seed yield and total $P$ uptake, there were no significant differences attributed to placement methods. Placement methods included surface broadcast and mixing into the top $8 \mathrm{~cm}$ of soil. surw face broadcast and left on the soil, banding $4 \mathrm{~cm}$ from the row and banding $4 \mathrm{~cm}$ from the row and $8 \mathrm{~cm}$ deep. Brazilian soybean growers also commonly use corrective and maintenance fertilizers banded near the seed at planting time. Hanson (1979) undertook a study to evaluate the influence of broad. cast and incorporated $P$ vs $P$ banded near the seed, upon yield and leaf composition of Bragg cultivar soybeans. Rates of 0 , 35. 70 and $140 \mathrm{~kg} P /$ ha were banded and/or broadcast on Sao Jeronomo silt loam soil. low in available $P(5.3 \mathrm{ppm})$. Results indicated that banding near the seed increased $P$ uptake vs broadcast and incorporated. However, increased lodging in the banded treatments, probably resulting from an imbalance in the $P: K$ ratio in the plant tissue, resulted in yield reduction to the extent where broadcasting of $\mathrm{P}$ proved to be somewhat better in terms of seed yield. The immediate maximum economic benefit was from broadcast-P treatments which suggested that factors other than phosphorus uptake per se, 
prevented greater $P$ uptake from banded treatments from being translated into greater seed yields.

The influence of soil reaction ( $\mathrm{pH}$ ) on the yield of soybeans was studied by Feevy et al (1972) as part of a larger study which also considered the effects of residual soil phosphorus and fertilizer phosphorus. The crop was grown on Olivier silt loam in Lousiana and production at $\mathrm{pH}^{\circ} \mathrm{s}$ ranging from 5.1 to 7.0 was investigated. The authors found that yields were low (20 to 24 bushels per acre) at a soil pH of 5.I at all soil phosphorus levels, with or without the use of phosphorus fertilizer. At pH 5.6, yields with or without $P$ fertilizer, were 6 to 8 bushels per acre higher and there was also more response to fertilizer phosphorus. At pH 6.4 yields without fertilizer $P$ were considerably higher than at pH 5.6 or 5.I, but the response to fertilizer $\mathrm{P}$ was less than at $\mathrm{pH}$ 5.6. The highest yields were produced at $\mathrm{pH} 7.0$. The yields were higher at $\mathrm{pH} 7.0$ without fertilizer phosphorus than they were with fertilizer phosphorus at any other lower pH value. The data indicated that the soils should be limed to $\mathrm{pH} 7.0$ and that the extractable soil phosphorus level should be about 35 to $40 \mathrm{ppm} P$ for good soybean yields. Even though responses to fertilizer $P$ may not be obtainable under these conditions, the authors felt that the use of small amounts of phosphorus may be desirable to help promote early growth and maintain the soil phosphorus level. 
D. YIELD AND CHEMICAL COMPOSITION

OF SOYBEANS: EFFECT OF P

Ohlrogge (1960) in reviewing the current state of knowledge on the mineral nutrition of soybeans, pointed out that a diagnosis of the mineral nutrition probiem can be facilitated by knowledge of "the cardinal concentrations in the total plant and plant parts which define and separate deficiency, adequacy and luxury levels of nutrition". Even though the existing literature was not very definitive on this subject with respect to soybean, the writer managed to quote several values for critical, optimum and luxury levels of various elements in the plant for various stages of growth. Thus at the prebloom stages, $0.25 \% \mathrm{P}$ in the plant tops was considered critical while the optimum range was considered to be $0.25 \%$ to $0.45 \%$. Data reviewed also indicated that at the pod-filling stage, a critical concentration for the tops, exclusive of seeds would be $0.05 \% \mathrm{P}$ while the optimal range would be between $0.25 \%$ and $0.35 \%$. Nutrient absorption is usually rapid in relation to dry matter accumulation during the early growth stages and it has been stated that from 70 to almost $100 \%$ to total plant $P$ in the early stages can be derived from fertilizer (Ohlrogge, 1960). In the later developmental stages the nutrient concentration of the various parts generally decreases; this process beginning well before translocation into the seed comes into effect. Hanway and Weber (1971, I) pointed out that $P$ translocation from pods to seed took place after 
about 80 days of growth until maturity. Pods at 80 days were observed to contain $0.4 \%$ and this rapidly decreased to $0.05 \%$, while seeds of a number of soybean varieties contained $P$ ranging from 0.57 to $0.71 \%$ at maturity.

The rate of nutrient accumulation relative to that of dry matter has bearing on the nutrient needs at various stages of development of the plant. Hanway and Weber (1971. II) determined dry matter production and percentage composition in various parts of soybean plants grown on Nicollet silty clay loam, at 10 stages of development. Total accumulation pattems of $N, P$ and $K$ followed patterns similar to dry matter accumulation; the rates increased prior to full bloom, decreasing to zero after the "green bean" stage. Average accumulation rate of $P$ was $0.4 \mathrm{~kg} / \mathrm{ha} /$ day for the period between full bloum to seed filling. while total dry weight increased at a rate of $176 \mathrm{~kg} / \mathrm{ha} /$ day for the same period. Cumulative nutrient distribution curves determined by the authors, showed that approximately $45 \%$ of the $P$ was absorbed after the beginning of bean formation when the vegetative plant parts had nearly reached their maximum content. All of this or its equivalent, probably went into the seed because grain contained $73 \%$ of the $P$ absorbed by the plant. Harper (1971) found in field hydroponic gravel culture systems that uptake of $\mathrm{N}, \mathrm{P}, \mathrm{K}, \mathrm{Ca}$ and $\mathrm{Mg}$ were low in the first 30 days, increasing sharply at initial flowering and reaching maximum rates between full 
bloom and mid-pod-fill. Uptake of the major nutrients generally declined through later developmental stages. P toxicity symptoms were observed at initial flowering due to the high nutrient level imposed. Moisture stress has been shown to have an effect on accumulation rates of the major nutrients. dellooy et al (1976) pointed out that maximum accumulation rates of $\mathrm{N}$ and $\mathrm{P}$ and to a lesser extent $\mathrm{K}$ and $\mathrm{Mg}$, were reached sooner in a dry year than in a season with adequate moisture.

The effect of fertilization on crop yields has been frequently studied by determining the treatment effect upon chemical composition of the plant or plant parts and relating plant content of the fertilizer elements to yields. Even though soybean response to direct mineral fertilization has been inconsistent, yield increases, where they have been reported, have often been attributed to phosphorus fertilization. Miller et al (1961) carried out an experiment on Dickinson fine sandy loam, low in avajlable $P$ and very low in available $K$, to determine (a) the effects of $P$ and $K$ fertilizers on yield and soybean plant composition and (b) the growth stages and plant part whose chemical composition best correlated with yields. While yield increases were shown to be more closely associated with increase in $K$ content than with $P$ content. it was possible to account for over $80 \%$ of the yield variation by multiple regression equations containing the two variables. $\% \mathrm{P}$ and $\% \mathrm{~K}$. Soybean yields were also closely associated with 
$P$ and $K$ content of the upper leaves sampled at the podding stage. demooy and Pesek (1970) also noted that the $P$ content of soybean leaves is of "primary interest for grain production". In an experiment designed to evaluate the differential effects of $P, K$ and $C a$ salts of leaf composition, yield and seed size of different soybean lines, the researchers found that varietal differences in grain yield response were mainly caused by $P$ and $\mathrm{P} \times \mathrm{Ca}$ interaction factors. $\mathrm{P}$ application a a rate of $510 \mathrm{pp} 2 \mathrm{~m}$ of Clarion silt loam $(3.9 \mathrm{~kg} \mathrm{P} / \mathrm{ha})$ raised $\mathrm{P}$ content at the end of flowering from 35.6 to $375 \mathrm{mg}$ per pot and effected a tripling of seed yield over the check treatments. The authors noted that in cases where no responses are obtained on soils low in native phosphorus, one possible reason might be that a relatively large portion of the root system is growing in unfertilized zones of the soil - a situation that is typical under especially dry conditions.

Yield responses to direct $P$ and $K$ fertilization by soybeans is, nevertheless, inconsistent. Hanway and Weber (1971, III) found that moderate rates of $P$ and $K(49$ and $229 \mathrm{~kg} / \mathrm{ha}$ respectively) had relatively small effects on different plant parts and seed yields, when these fertilizers were applied on Nicollet silt loam (15pp2m P). Bhangoo and Albritton (1972) also reported small and non-significant yield increases to application of $P$ on a low $P$ soil. A $12.1 \%$ increase in yield was recorded in the first year of a three-year study but this 
was small compared to increases attributed to $N$ and $K$. It should be noted this experiment was affected by moisture stress in the rirst year and as was noted by dellooy and Pesek (1970), this may have affected responses to $P$. On the other hand, more favourable responses to $P$ fertilization was reported by Islam (1974) who worked with soybeans on a medium fertile Canover silt loam soil $(34.7 \mathrm{~kg} / \mathrm{ha}$ available $P$ ). Use of triple supexphosphate at rates up to $224 \mathrm{~kg} / \mathrm{ha} P$, increased dry weights of leaves and stems and the $224 \mathrm{~kg} \mathrm{P} / \mathrm{ha}$ treatment significantly increased seed yield. However, rates in excess of this adversely affected potassium uptake and this tended to be reflected in reduced seed yields. Use of TSP resulted in increased accumulation of the divalent cations, calcium and magnesium and also increased total sugar and alpha-amino nitrogen contents of the plants.

Various attempts have been made to use soil test and crop response data to predict fertilizer requirements of crops. The critical value approach which requires a knowledge of tissue concentrations of the various elements has been used with some success. Peaslee (1978) mathematically put together data relating to soil tests for $\mathrm{P}$ and crop response by corn. soybean, alfalfa and clover-grass, to predict fertilizer requirements of these crops. Response curves and fertilizer requirements indicated that soybean yielded relatively more than the other three crops at low soil test levels of $P$. 
Maximum yields of soybean were $2020 \mathrm{~kg} / \mathrm{ha}$ but was affected by adverse weather. This yield was achieved by applying 224 $\mathrm{kg} P /$ ha as superphosphate broadcast on ploughed soil followed by discing, on a soil with a test level of $44 \mathrm{~kg} \mathrm{P} / \mathrm{ha}$.

Sumner (1977) noted that the critical or sufficiency level approach is limited by its inability to deal satisfactorily with variation in nutrient content with age. This system, he noted, required the sampling of leaves or other organs at a particular developmental stage, which may be shown to be best associated with yield. This often results in a range of concentration being quoted; such ranges being often quite wide and not particularly sensitive. He used Beaufil's Diagnosis and Recommendation Integrated System (DRIS) with some success on soybean yield data. This system is used to predict the fertilizer and other treatments required for a given crop at a given site to enhance the chances of obtaining a higher yield. It lists the major elements in order of the most limiting - with respect to yield and each is given a rating. Further applications of fertilizers are then made with these ratings in mind. Sumner tested prelininary norms for $N, P$ and $K$ in soybean leaves and found that the system appeared to be useful in diagnosing and ordering the most limiting and excessive elements. The DRIS approach has advantages over the critical value method:- (I) it can be used irrespective of age, variety and position of leaf sampled; 
(2) it is capable of giving a relative ranking of these elements in terms of the plant requirement; (3) the effects of appropriate and inappropriate treatments can be readily distinguished. 


\section{CHAPTER III}

\section{MATERIALS AND METHODS}

\section{A. GROWTH CHAMBER EXPERIMENTS}

The soil used for the two growth chamber experiments was obtained from the Portage La Prairie area, from the same site. Before being used the soil was seived, using a $2 \mathrm{~mm}$ sleve and then air-dried for at least 48 hours. Table 1 shows the physical and chemical characteristies of the soil.

\section{First Growth Chamber Experiment}

This experiment was designed to study the pattern of phosphorus uptake by soybean, when various rates of phosphorus were applied to decreasingly smaller volumes of soil within the pots. Table 2 shows the treatment structure used in the experiment and gives the effective concentration of fertilizer phosphorus within the zone of application. Phosphorus was applied as mono-calcium phosphate dinydrate $\left(\mathrm{Ca}\left(\mathrm{H}_{2} \mathrm{PO}_{4}\right) 2.2 \mathrm{H}_{2} \mathrm{O}\right)$ which was dissolved and appropriately sprayed on to the various volumes of soil in $10 \mathrm{ml}$ aliquots, to ensure uniform application. Phosphorus treatments were labelled with radioactive $32 \mathrm{P}$ in the form of ortho-phosphoric acid, in order to properly quantify the amount of phosphorus obtained by the plants from the fertilizer source. Two millicuries of $32 \mathrm{P}$, obtained from New England Nuclear, was diluted in $100 \mathrm{ml}$ deionised water. Twenty $\mathrm{ml}$ of this was added to each of the 20 to $40 \mathrm{ppm} \mathrm{P}$ solutions and $40 \mathrm{ml}$ 


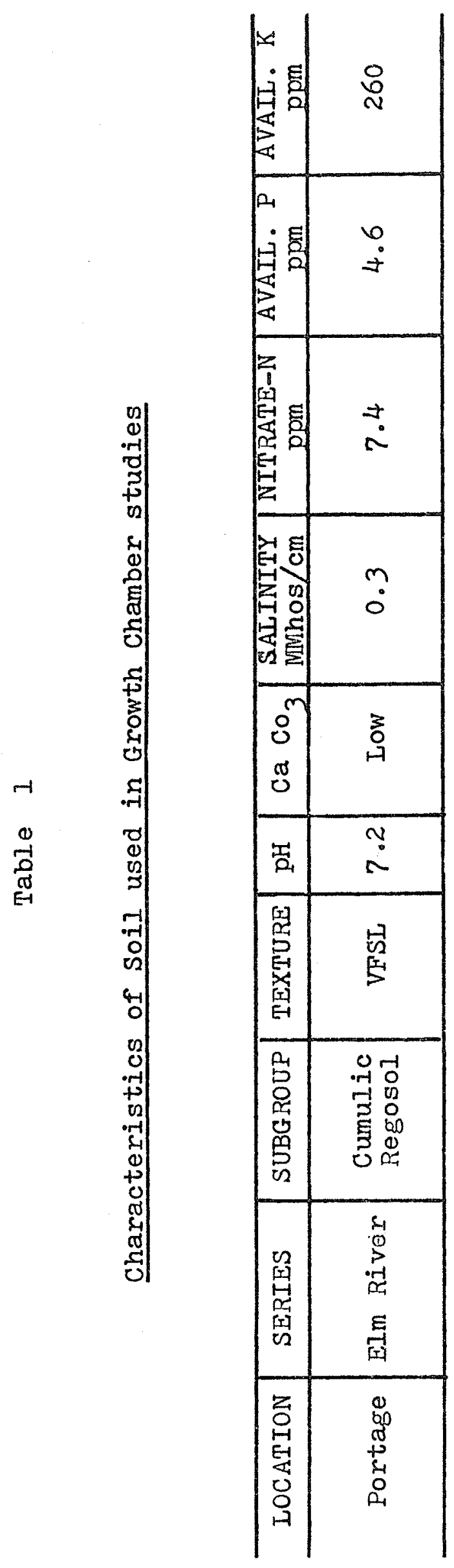


TABLE 2

TREATMENT STRUCTURE FOR PHOSPHORUS APPLICATIONS

First Growth Chamber Experiment

\begin{tabular}{c|rrr}
\cline { 2 - 3 } & \multicolumn{3}{|c}{ Rate of Applied Phosphorus (gm/pot) } \\
\hline Soil Volume Treated & 0.1 & 0.2 & 0.4 \\
\hline $100 \%(5000 \mathrm{gm})$ & $20 \mathrm{ppm}$ & $40 \mathrm{ppm}$ & $80 \mathrm{ppm}$ \\
$50 \%(2500 \mathrm{gm})$ & $40 "$ & $80 "$ & $160 "$ \\
$25 \%(1250 \mathrm{gm})$ & $80 "$ & $160 "$ & $320 "$ \\
$12.5 \%(625 \mathrm{gm})$ & $100 "$ & $320 "$ & $640 "$ \\
$1 \%(50 \mathrm{gm})$ & $2000 "$ & $4000 "$ & $8000 "$ \\
Control & \multicolumn{3}{|c}{ No Phosphorus Added } \\
\hline
\end{tabular}

Note 1: Each treatment was replicated three times to give a total of 48 observations.

Note 2: Except in the case where $P$ was mixed throughout the soil $(100 \%)$, the top of the treated band was placed so as to be $2.5 \mathrm{~cm}$ below the seeds.

Note 3: Values given in table refer to effective concentration of fertilizer $P$ within the fertilized zones. 
to the 80 ppm $P$ solution, before each was made up to I litre volume.

Additional fertilizer treatments consisting of Nitrogen, Potassium, zinc and Copper were applied in solution to each pot as follows: - $\mathrm{N}$ as $\mathrm{NH}_{4} \mathrm{NO}_{3}(100 \mathrm{pprn}): \mathrm{K}$ as $\mathrm{K}_{2} \mathrm{SO}_{4}$ (200 ppin): $\mathrm{Zn}$ as $\mathrm{Zn} \mathrm{So}_{4}(8 \mathrm{ppm})$ and $\mathrm{Cu}$ as $\mathrm{Cu} \mathrm{Cl}_{2}(6 \mathrm{ppm})$. These treatments were applied in 10 aliquots and well mixed with the soil just prior to planting. At 30 days after planting each pot received an additional application of $100 \mathrm{ppm} \mathrm{N}$.

Soybean seeds of the Maple Presto variety were pregerminated in wet tissue paper before being sown at a rate of 5 seeds per pot at about $2 \mathrm{~cm}$ below the soil surface. Deionised water was added to bring the soil to $50 \%$ of Field Capacity and the pots were placed in random order in the growth chamber. Conditions in the growth chamber were set as follows:- Temperature: $15^{\circ} \mathrm{C}$ (night) $-20^{\circ} \mathrm{C}$ (day): Daylength: - 15 hours -8 a.m. to 11 p.m.8 Humidity: - 80\% (night) - 50\%(day). The light intensity measured at 30 days after planting and subsequently, ranged from 500 to 550 microeinsteins $\mathrm{M}^{-2} \mathrm{sec}^{-1}$ within and above the canopy.

Planting was done on october 15, 1979, with emergence being observed four days later. Pots were watered on a daily basis to bring the soil to Field Capacity (23.8\%). The plants were thinned to two per pot after 10 days and the experiment was allowed to run for 44 days i.e. 14 days after flowering. Plant 
tops were then harvested, washed and placed to dry in the oven at $60^{\circ} \mathrm{F}\left(15.5^{\circ}\right)$ for 48 hours. The dry weights were taken and plants ground for labrotary analysis.

\section{Second Growth Chamber Experiment}

This experiment was carried out to observe the influence of placement of phosphorus in relation to the seed, on the upo take of phosphorus from soil and fertilizer and on the dry matter yield of soybean plants. The soil used was the same as described for the rirst growth chamber study and was prepared in the same manner. Two rates of applied phosphorus were used in this study $0.2 \mathrm{gm} P$ and $0.4 \mathrm{gm} P$ per $5 \mathrm{~kg}$ soll. Each rate was applied in one of 6 locations as a narrow band (approximately $1.5 \mathrm{~cm}$ ) either directly below or below and away from the seeds. In order to compare these placement methods with the best treatments from the first growth chamber experiment, additional treatments were utilized, where $1 \%$ of the soil volume was treated with each rate of applied $P$ and the treated soil spread as a wide band $2.5 \mathrm{~cm}$ below the seeds. The bands were placed at $2.5 \mathrm{~cm}$ and $5 \mathrm{~cm}$ below the seed, directly below or $2.5 \mathrm{~cm}$ and $5 \mathrm{~cm}$ away.

Phosphorus was applied as mono-calcium phosphate dihydrate $\left(\mathrm{Ca}\left(\mathrm{H}_{2} \mathrm{PO}_{4}\right)_{2} \cdot 2 \mathrm{H}_{2} \mathrm{O}\right)$. Appropriate amounts of the salt were weighed out and dissolved in deionised water. Solutions of 40 and 80 ppm $\mathrm{P}$ were made up in this manner. Two millicuries of ${ }^{32} \mathrm{P}$, obtained from New England Nuclear, was diluted in $100 \mathrm{ml}$ deionised water. Twenty $\mathrm{ml}$ of this was added to the $40 \mathrm{ppm} P$ solution and $40 \mathrm{ml}$ to 
the $80 \mathrm{ppm} P$ solution, before each was made up to a volume of $250 \mathrm{ml}$. Individual pots were appropriately treated with $10 \mathrm{ml}$ of phosphate solution. 15 treatments including a check, were each replicated three times to give a total of 45 observations in a completely randomised design.

Additional fertilizer treatments consisting of Nitrogen. Potassium, Zinc and Copper were applied to each pot as follows:$\mathrm{N}$ as $\mathrm{NH}_{4} \mathrm{NO}_{3}(100 \mathrm{ppm}) ; \mathrm{K}$ as $\mathrm{K}_{2} \mathrm{SO}_{4}(200 \mathrm{ppm}) ; \mathrm{Zn}$ as $2 \mathrm{nSO}_{4}$ (8 ppm) and $\mathrm{Cu}$ as $\mathrm{CuCl}_{2}(6 \mathrm{ppm})$. These were applied before planting. An additional application of $100 \mathrm{ppm} N$ was done 30 days after planting.

Pre-germinated soybean seeds of the Maple Presto variety were sown at $2.5 \mathrm{~cm}$ below the soil surface, at a rate of 4 seeds per pot. Seeds were planted in a row which bore the appropriate relation to the fertilized band. Planting was done on April 8, 1980; water was added to bring the soil to $50 \%$ of Field Capacity and the pots placed in random order in the growth chamber. The growth chamber conditions were the same as described for the first experiment. Plant tops were harvested 44 days after planting. washed and placed in the oven at $60^{\circ} \mathrm{F}\left(15.5^{\circ} \mathrm{C}\right)$ for 48 hours. Oven-dry weights were taken and the plants ground for laboratory analysis.

\section{B. FIELD EXPERIMENTS}

Two field studies with respect to phosphorus uptakevoy. 
soybean, were undertaken during the summer of 1979. One study was carried out at three different sites in Manitoba and was aimed at comparing three different rates of added phosphorus on soils of varying phosphorus fertility. The other combined four rates of added phosphorus with five placement methods. The latter was part of a larger phosphorus placement study involving crops other than soybeans, carried out under the auspices of the Brandon Research Station. The study was duplicated at two sites, one at Brandon and the other at Nee pawa.

\section{Phosphorus Placement Study}

Table 3 shows the characteristics of the two soils used for this study. The data presented are on the basis of soil samples taken in the spring of 1979. just prior to seeding. The sites had been selected before that, on the basis of previous soil analyses. It should be noted that the selection process took into account the differences in texture at the two sites; one being sandy and the other predominantly clay. Both sites were treated with granular Treflan in the Fall of 1978, for weed control purposes.

Rates of added phosphate ranged from 0 to $120 \mathrm{~kg} / \mathrm{ha}$ $\left(\mathrm{P}_{2} \mathrm{O}_{5}\right)$, while the placement methods were (1) Fall broadcast and worked in, (2) spring broadcast and worked in. (3) Fertilizer placed with the seed, (4) sidebanding $2.5 \mathrm{~cm}$ below and 
TABLE 3

Characteristics of Soils Used In

Phosphorus Placement Study

\begin{tabular}{lll}
\hline Location & Neepawa & Brandon \\
Soil Association & Newdale & Miniota \\
Texture & Clay & Sandy Loam \\
$\mathrm{pH}$ & 7.5 & 7.0 \\
Conductivity (mmos $/ \mathrm{cm})$ & 0.40 & 0.32 \\
$0-15 \mathrm{~cm} \mathrm{P}(\mathrm{kg} / \mathrm{ha})$ & 4.8 & 4.3 \\
$0-15 \mathrm{~cm} \mathrm{~K}(\mathrm{~kg} / \mathrm{ha})$ & 740 & 98 \\
$0-60 \mathrm{~cm} \mathrm{~N}(\mathrm{~kg} / \mathrm{ha})$ & 22.5 & 18.8 \\
$0-60 \mathrm{~cm} \mathrm{~S}(\mathrm{~kg} / \mathrm{ha})$ & 27.5 & 17.6 \\
\hline
\end{tabular}

TABLE 4

Monthly Rainfall At The Two Sites

Over The Growth Period

\begin{tabular}{c|c|c|c|c}
\hline SITE & \multicolumn{4}{|c}{ MONTHLY RAINFALI (mm) } \\
\hline \multirow{3}{*}{ Brandon } & May & June & JuIy & August \\
\cline { 2 - 5 } Neepawa & 77 & 26 & 26 & 13 \\
& 65 & 28 & 45 & 20 \\
\hline
\end{tabular}


$2.5 \mathrm{~cm}$ to the side, (5) Placed $2.5 \mathrm{~cm}$ directly below the seed. Fall broadcast treatments were applied in october 1978 while spring broadcast along with the other treatments were applied in May 1979, just prior to planting. A specially designed seeder was used to carry out all seeding and fertilizer placements. Phosphate was applied as $0-46 \times 0$.

In addition to phosphorus, each plot received potassium and sulphur fertilizers which were applied as blanket treatments at rates of $120 \mathrm{~kg} \mathrm{~K} \mathrm{~K}_{2} \mathrm{ha}$ and $60 \mathrm{~kg} \mathrm{~S} / \mathrm{ha}$. Soybean seeds (Maple Presto variety) were inoculated before planting. Monthly rainfall experienced at both sites over the cropping period is given in Table 4.

This experiment formed part of a larger study of the effects of different placement methods for phosphorus on several crops. The experimental design at each site was identical. The crop was planted in three plots which constituted replicates, each 6 metres wide and 25.2 metres long. In each plot there were 21 subplots representing the treatments which were separately randomised within each plot. All plots were seeded to give a stand of $70-80$ plants $/ \mathbb{M}^{2}$ with 6 rows per subplot. Plant counts were taken at the first trifoliate stage and except for the $120 \mathrm{~kg} \mathrm{P}_{2} \mathrm{O}_{5} /$ ha treatments, where counts ranged from $47-56 / \mathbb{M}^{2}$, counts at both sites fell within the range of $68-75$ plants $/ \mathrm{m}^{2}$. It should also be noted that mechanical problems with the seeder resulted in the loss of 
one subplot at the Brandon site. During the growth of the crop, plant samples were taken at various stages as shown in Table 5 .

TABLE 5: Sampling and Harvest Dates for Phosphorus Placement Study

\begin{tabular}{l|l|l}
\hline SITE & STAGE OF SAMPING & DATE \\
\hline Brandon & First Trifoliate & June 28,1979 \\
Brandon & Flowering & July 10,1979 \\
Brandon:! & Full-pod & July 30,1979 \\
Brandon & Maturity & August 21,1979 \\
Neepawa & First Trifoliate & July 6, 1979 \\
Neepawa & Flowering & July 17.1979 \\
Neepawa & Full-pod & August 7.1979 \\
Neepawa & Maturity & September 6, 1979 \\
\hline
\end{tabular}




\section{Rate Study}

Three farm sites in southern Manitoba were chosen to carry out a study of soybean response to various rates of applied phosphorus. The physical and chemical properties of the soils are reported in Table 6. The names used, refer to the farmers on whose sites the experiment was conducted. Maple Presto variety was again used in this study.

The sites were identical with respect to experimental design. The crop was grown in $91 \mathrm{~cm}$ rows, with each treatment consisting of 3 rows of crop contained in a sub-plot with dimensions $7.62 \mathrm{~m} \times 2.74 \mathrm{~m}$. The blocks were separated by 1.5 metre pathways and the entire plot surrounded by 3.7 metre guard rows or by other experiments being run simultaneously.

Before seeding. Treflan was applied at each site, for weed control purposes. Basic fertilizer treatments of $S, N$ and $K$ were applied at each site at the following rates:- $30 \mathrm{~kg}$ $\mathrm{S} / \mathrm{ha}, 30 \mathrm{~kg} \mathrm{~N} / \mathrm{ha}$ and $100 \mathrm{~kg} \mathrm{~K} / \mathrm{O} / \mathrm{ha}$. Phosphorus in the form of mono-calcium phosphate was side-banded $5 \mathrm{~cm}$ below and $5 \mathrm{~cm}$ to the side at rates of 30 and $100 \mathrm{~kg} \mathrm{P} \mathrm{P}_{5} / \mathrm{ha}$.

The experiment used a randomised complete block design with each treatment being replicated four times. The crop was allowed to grow to maturity at which time a plot size of $60 \mathrm{~cm} \times 3 \mathrm{~m}$ was harvested for each replicate for purposes of obtaining grain yield. 
TABLE 6

Characteristics of Soils Used in Rate Study

\begin{tabular}{|c|c|c|c|}
\hline & \multicolumn{3}{|c|}{ SITES } \\
\hline & Nikkel & Toews & Enns \\
\hline Soil Type & Neuemberg & Hockfield & Reinlano \\
\hline Soil Texture & VFSI & FSL & FSI \\
\hline $\mathrm{pH}(0-15 \mathrm{~cm})$ & 8.2 & 7.2 & 7.4 \\
\hline$\%$ Organic Matter & 2.53 & 2.30 & 2.53 \\
\hline Conductivity $(\mathrm{mmhos} / \mathrm{cm})$ & 0.26 & 0.17 & 0.16 \\
\hline$\% \mathrm{CaCO}_{3}$ & 2.28 & 0.57 & 1.22 \\
\hline $\mathrm{NO}_{3}-\mathrm{N}(\mathrm{kg} / \mathrm{ha})$ & 48.32 & 13.27 & 13.58 \\
\hline $\begin{array}{l}\mathrm{P}-\mathrm{PO}_{4}(\mathrm{~kg} / \mathrm{ha}) \\
\quad\left(\mathrm{NaCO}_{3} \text { extractable }\right)\end{array}$ & 17.15 & 27.69 & 29.66 \\
\hline $\mathrm{K}\left(\begin{array}{l}\mathrm{kg} / \mathrm{ha}) \\
\left.\mathrm{NH}_{4} \mathrm{OAC} \text { extractable }\right)\end{array}\right.$ & 174.65 & 261.98 & 250.26 \\
\hline$S(\mathrm{~kg} / \mathrm{ha})$ & 140.69 & 15.33 & 17.72 \\
\hline
\end{tabular}


C. ANALYTICAL PROCEDURES

\section{Total Phosphorus}

Plant tissue from the two growth chamber experiments were first oven-dried and ground. Each sample was then analysed in triplicate. For each replicate, I gm of plant material was digested using nitric and perchloric acid digestion. The resulting filtrate was diluted to $50 \mathrm{ml}$. From this, $1 \mathrm{ml}$ was diluted in $10 \mathrm{ml}$ water and another 1:10 dilution followed. A complexing reagent was made up by adding $20 \mathrm{ml}$ ascorbic acid solution ( $2.5 \mathrm{gm}$ dissolved in $100 \mathrm{ml}$ ) to $80 \mathrm{ml}$ of acid molybdate-antimony solution (previously made-up). $2 \mathrm{ml}$ of this reagent was added to each of the samples and they were left to stand while a blue colour developed. After 15 minutes, readings were taken on a spectrometer at $885 \mathrm{m \mu}$.

A standard phosphate curve was obtained by using phosphate solutions ranging from 0.1 to $10 \mathrm{ppm} P$ and complexing these with the mixed reagent. Total phosphorus in the plant tissues was then calculated from calibration on the standard curve and taking into account the dilutions as well as the dry weights of the individual treatment replicates. The same procedure was used to calculate total phosphorus uptake in the phosphorus placement field experiment. The Kjeldhal method for determining total nitrogen was used to analyse grain samples from the latter study. 


\section{Phosphorus Derived From Fertilizer}

Two different procedures were utilised to determine phosphorus derived from fertilizer in the two experiments which involved the use of ${ }^{32} \mathrm{P}$. In the first experiment. radioactive counts were taken by the end-window method on a Geiger-Muller counter. Due to the unavailability of this machine at the time of the second growth chamber experiment, an alternative method of counting was employed. Thus, samples were analysed on a liquid scintillation system in a searle Mark III Liquid Scintillation Counter (Model 6880).

For the first method, I $\mathrm{ml}$ of the filtrate from digestion was pipetted on to a planchette and placed to dry with the aid of a infra-red lamp. Three standards were made up by diluting $20 \mathrm{ml}$ of each of the 20,40 and $80 \mathrm{ppm} P$ solutions, to $50 \mathrm{ml}$. I $\mathrm{ml}$ of each of these was similarly placed to dry on a planchette. Radioactive counts for each sample were taken on a Geiger-Muller counter in such a manner that similarly treated plant samples were counted in a batch along with the appropriate standard. Background count was also taken after each sample and subtracted. Percent phosphorus derived from the fertilizer source was calculated as follows:-

$$
\% \text { Pdff }=\frac{\text { Specific Activity of Sample }}{\text { Specific Activity of Standard }} \times 100
$$

Specific Activity = Counts/Min/mgm $P$ in $1 \mathrm{ml}$ of solution. 
A similar method was used to calculate \%pdrf in the second growth chamber experiment. However, the procedure was altered in order to effectively utilize the machine. In this case. $15 \mathrm{ml}$ portions of the filtrates were pipetted into special containers which are used to count radioactivity on the Liquid Scintillation Counter. Standards for this procedure were prepared by diluting $0.1 \mathrm{ml}$ of each of the 40 and $80 \mathrm{ppm} P$ solutions in $15 \mathrm{ml}$ water. Water blanks were also included for the purpose of obtaining background counts. 
CHAPTER IV

\section{RESULTS AND DISCUSSION}

\section{A. First Growth Chamber Experiment}

In this experiment, five differently sized bands of soil were treated with three rates of phosphorus fertilizer and the resulting effect on soybean plants was evaluated in terms of dry matter yield, total phosphorus uptake and phosphorus derived from the fertilizer. Dry weights and other parameters relating to phosphorus uptake were taken for plant tops harvested after 44 days of growth. The experiment was designed to study the relationship between $P$ uptake vs varying $P$ concentrations in the soil and root volumes within the zone of $P$ fertilizer reaction.

The results show a significant response to the addition of phosphorus, both in terms of dry matter yield and phosphorus uptake (Tables $7 \& 8$ ). The soil used in this study had no previous history of fertilization even though it had been cropped for several years. Soil tests revealed a native level of $4.6 \mathrm{ppm}$ $\mathrm{P}$ ( $\mathrm{NaHCO}_{3}$ extractable) which classifies it as being low in available P (Thomas and Peaslee, 1973). Previous studies had found that soybeans respond poorly to $P$ fertilization especially on soils with medium to high $P$ fertility, in both field and greenhouse studies (Krantz et al, 1949 and Kalra and Soper, 1968. delooy and Pesek (1970) had reported significant pesponses in yield 
among soybean lines from pot experiments in which soil testing low in available $P(3.9 \mathrm{~kg} \mathrm{P} / \mathrm{ha}$ by Bray No. I extractant) had been used. Such responses were however, obtained with the use of $P$ application rates ranging from 100 to 800 pp2m $P$. Favourable responses to $P$ application by soybean on low-l soils have been reported elsewhere (Ham and Caldwell, 1978 and Hanson, 1979). The latter two studies were however conducted in the field where plant demand for applied $P$ is usually much less than in pot studies.

Observations made during the growth of the crop showed that a definite response to $P$ fertilization was evident after the first three weeks of growth. Beyond this point, treatment differences became increasingly clear. Just prior to and during flowering, the growth rate of fertilized plants had increased rapidly while the unfertilized plants seemed to have attained maximum height. Comparison of dry matter yields obtained in this experiment (Table 7) shows that dry weights attained in control pots were nearly doubled by the addition of the lowest amount of fertilizer $P$. The best yield which was obtained by adding $0.4 \mathrm{gm} \mathrm{P} /$ pot to $1 \%$ of the soil was five times that achieved in control pots.

Dry matter yields with the lowest amount of $P$ added, increased steadily with decrease in size of the treated band. Statistically significant differences in yield were obtained when $100 \%$ of the soil was phosphated as against $12.5 \%$ and $1 \%$ 


\section{TABLE ?}

DRY MATTER YIELDS OF SOYBEAN PLANTS AS AFFECTED BY RATE OF PHOSPHORUS FERTILIZATION AND VOIUUME OF SOIL TREATED

\begin{tabular}{c|ccc}
\cline { 2 - 4 } & \multicolumn{3}{|c}{ Phosphorus Added (gm/pot) } \\
\hline Soil Volume Treated & 0.1 & 0.2 & 0.4 \\
\hline \multirow{3}{*}{ Control } & $8.67 \mathrm{a}$ & $8.67 \mathrm{a}$ & $8.67 \mathrm{a}$ \\
$100 \%$ & $16.17 \mathrm{~b}$ & $24.73 \mathrm{~b}$ & $37.07 \mathrm{~b}$ \\
$50 \%$ & $17.28 \mathrm{~b}$ & $32.08 \mathrm{c}$ & $39.82 \mathrm{bc}$ \\
$25 \%$ & $22.53 \mathrm{bc}$ & $38.04 \mathrm{~d}$ & $42.08 \mathrm{bc}$ \\
$12.5 \%$ & $24.90 \mathrm{c}$ & $38.70 \mathrm{~d}$ & $42.78 \mathrm{bc}$ \\
$1 \%$ & $26.23 \mathrm{c}$ & $39.26 \mathrm{~d}$ & $43.64 \mathrm{c}$ \\
\hline
\end{tabular}

Duncan's Multiple Range Test: Numbers followed by the same letter are not significantly different at the 5\% level. Separate analyses done for each rate. 


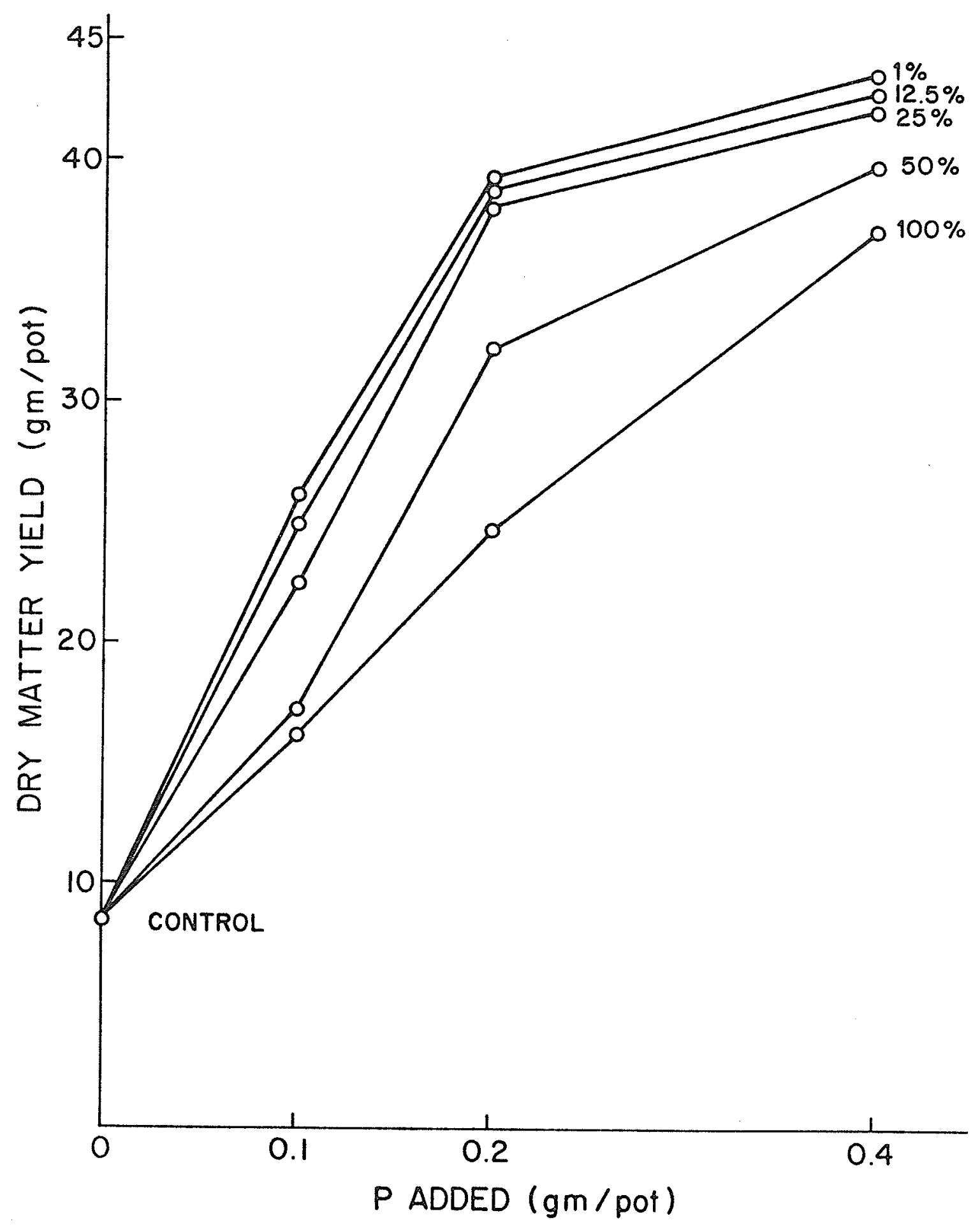

Figure 1: Pattern of Dry Matter Production by Soybean plants as affected by amount of Phosphorus added and Volume of Soil Treated. 
being treated. The latter treatment resulted in yields that were $62 \%$ higher than where $P$ was added throughout the soil. Reducing the size of the treated band had similar efrects when $0.2 \mathrm{gm} P$ was added to the soil. At this level, yield differences were also significant between $100 \%$ vs $12.5 \%$ and $1 \%$. Even though the yield differential between the largest and smallest bands here was $15 \mathrm{gm}$ (as against $10 \mathrm{gm}$ at the lower level of $P$ fertilization) the yield was increased by 59\%. At the highest level of $P$ fertilization, this yield differential had dropped to $6 \mathrm{gm}$ and differences were only significant between the largest and smallest band sizes.

This diminishing response with increase in fertilization rate which is illustrated in Figure 1. suggested that the plants had increased in size to the point where they were approaching maximum attainable dry weights under the conditions of the experiment. The graph shows yield increases were almost linear at the lower $P$ concentrations which implied that chemical availability of $P$ at these levels may have limited growth. At the higher $P$ concentrations i.e. at the I\% level, jield increases began to level off, as the plants were probably approaching maximum growth potential.

Total phosphorus uptake followed closely similar trends to those observed for dry matter yields (Table 8). Plants with the lowest amount of $P$ added, absorbed twice as much phosphorus as did plants with no $P$ added. The best uptake 
TABLE 8

TOTAL PHOSPHORUS UPTAKE BY SOYBEAN PLANTS AS AFFECTED

BY RATE OF FHOSPHORUS FERTILIZATION AND VOLUME OF SOIL TREATED

\begin{tabular}{c|ccc}
\cline { 2 - 4 } Soil Volume Treated & \multicolumn{3}{|c}{ Phosphorus Added (gm/pot) } \\
\hline \multirow{3}{*}{ Control } & 0.1 & 0.2 & 0.4 \\
$100 \%$ & $9.70 \mathrm{a}$ & $9.70 \mathrm{a}$ & $9.70 \mathrm{a}$ \\
$50 \%$ & $19.92 \mathrm{~b}$ & $33.47 \mathrm{~b}$ & $52.44 \mathrm{~b}$ \\
$25 \%$ & $22.58 \mathrm{~b}$ & $41.40 \mathrm{bc}$ & $58.05 \mathrm{~b}$ \\
$12.5 \%$ & $29.66 \mathrm{bc}$ & $43.80 \mathrm{bc}$ & $61.89 \mathrm{~b}$ \\
$1 \%$ & $33.75 \mathrm{c}$ & $44.74 \mathrm{bc}$ & $62.37 \mathrm{~b}$ \\
& $37.61 \mathrm{c}$ & $53.11 \mathrm{c}$ & $64.72 \mathrm{~b}$ \\
\hline
\end{tabular}

Duncan's Multiple Range Test: Numbers followed by the same letter are not significantly different at the $5 \%$ level. Separate analyses done for each rate. 


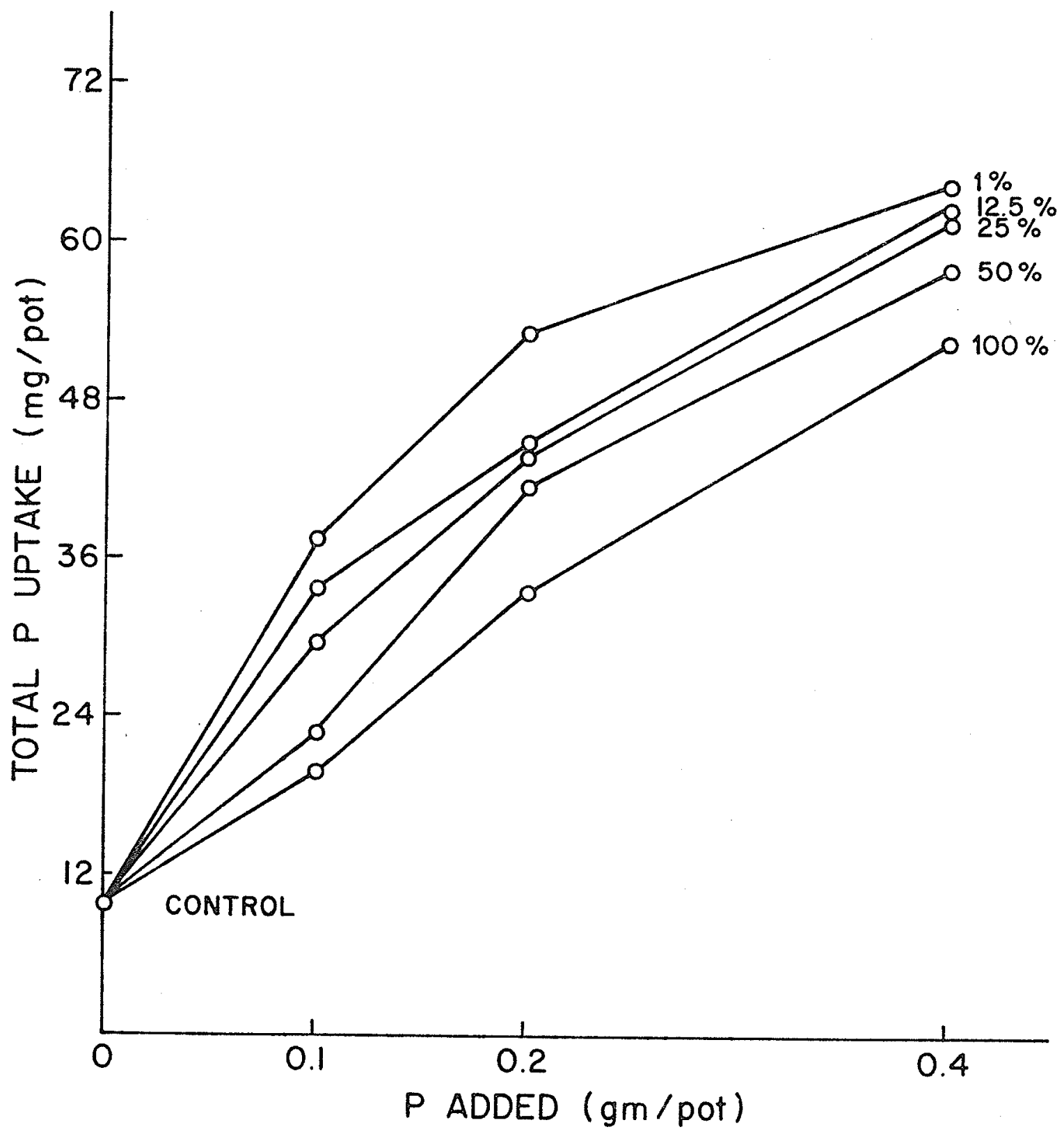

Figure 28 Pattern of $\mathrm{P}$ uptake by Soybean plants as influenced by amount of Phosphorus added and Volume of Soil Treated. 
was achieved in plants where $0.4 \mathrm{gm} \mathrm{P}$ was added to $1 \%$ of the soil and $P$ uptake here was six times that of control plants. At the lowest rate of fertilization, $P$ uptake was significantly increased by reducing the size of the treated band from $100 \%$ to $12.5 \%$ and $1 \%$. Uptake with the latter treatment was $89 \%$ better than that obtained by adding phosphorus throughout the soil. Similarly, with $0.2 \mathrm{gm} P$ added, uptake was increased by 59\% when $\mathrm{P}$ was placed in the smallest band size as against being mixed throughout. $P$ uptake with $12.5 \%$ and $1 \%$ of the soil treated were not significantly different but were superior to other treatments used. The trend towards greater total $P$ uptake from the smaller, more concentrated $P$ fertilizer source. continued at the highest level of fertilization. However, no significant differences were found at this rate when soil volume treated was decreased.

Figure 2 shows that total $P$ uptake followed a pattem quite similar to that observed with dry matter yield. With $P$ concentrations of 20,40 and $80 \mathrm{ppm} P$ (100\% soil treated), total $P$ uptake was almost linear. At the higher concentrations achieved by reducing the soil volume treated, uptake began to level off as the concentration of $P$ fertilizer increased. At the lower fertilizer P concentrations, uptake was probably limited by chemical availability of the nutrient. On the other hand, plant size probably became the limiting factor at the higher concentrations and as shown in the graph, the plants 
were unlikely to absorb much greater amounts of phosphorus. Pigure 2 also illustrates that total P uptake with $0.1 \mathrm{gm} \mathrm{P}$ added to $1 \%$ of the soil was greater than where the rate was doubled and fertilizer mixed throughout. Similarly, adding $0.2 \mathrm{gm} P$ to the smaller soil fraction proved to be superior, in terms of total P uptake, than mixing in $0.4 \mathrm{gm} P$ to the entire soil volume.

That phosphorus became increasingly available as the fertilizer source was made smaller, is further illustrated in Table 9. At each level of fertilization, phosphorus derived from the fertilizer increased with decrease in the soil volume treated. With $0.1 \mathrm{gm} P$ added, fertilizer $P$ uptake was significantly increased by adding this amount to $25 \%, 12.5 \%$ and $1 \%$ of the soil volume as against applying it to $100 \%$ and $50 \%$. Also, at the lowest level of fertilization, plants derived $35 \%$ of total $P$ from the fertilizer source when this was mixed throughout the soil as against $40 \%$ when fertilizer $P$ was confined to $1 \%$ of the soil. With $0.2 \mathrm{gm} P$ added, $43 \%$ of total $P$ was from the fertilizer mixed throughout but fertilizer $P$ uptake was significantly increased by adding $P$ to $12.5 \%$ and $1 \%$ of the soil where $52 \%$ and $53 \%$ of total $\mathrm{P}$ was from fertilizer. Treatment differences with the highest level of $P$ fertilization were less significant than at the other two rates, but even so plants with $1 \%$ of the soil volume phosphated, extracted up to $60 \%$ of their total $P$ supply from the fertilizer. The efficiency of fertilizer utilization (Table 10) was thus 
TABLE 9

EFFECTS OF RATE OF PHOSPHORUS FERTILIZATION

AND VOLUME OF SOII TREATED ON PHOSPHORUS

DERI VED FROM FERTILIZER BY SOYBEAN PLANTS

\begin{tabular}{c|ccc}
\cline { 2 - 4 } & \multicolumn{4}{|c}{ Phosphorus Added (gm/pot) } \\
\hline Soil Volume Treated & 0.1 & 0.2 & 0.4 \\
\hline & $60 \%$ & $(\mathrm{gm} /$ pot) \\
$50 \%$ & $8.16 \mathrm{ab}$ & $18.10 \mathrm{ab}$ & $30.87 \mathrm{ab}$ \\
$25 \%$ & $10.93 \mathrm{bc}$ & $21.19 \mathrm{~b}$ & $34.89 \mathrm{~b}$ \\
$12.5 \%$ & $12.72 \mathrm{c}$ & $23.32 \mathrm{bc}$ & $36.48 \mathrm{~b}$ \\
$1 \%$ & $15.10 \mathrm{c}$ & $28.40 \mathrm{c}$ & $38.87 \mathrm{~b}$ \\
\hline
\end{tabular}

Duncan's Multiple Range Test: Numbers followed by the same letter are not significantly different at the $5 \%$ level. Separate analyses done for each rate. 
TABLE 10

EFFICIENCY OF UTILIZATION OF FERTILIZER PHOS-

PHORUS AS AFFECTED BY RATE OF PHOSPHORUS

FERTILIZATION AND VOLUME OF SOIL TREATED

\begin{tabular}{c|ccc}
\cline { 2 - 4 } & \multicolumn{3}{|c}{ Phosphorus Added (gm/pot) } \\
\hline Soil Volume Treated & 0.1 & 0.2 & 0.4 \\
\hline $100 \%$ & $6.97 \mathrm{a}$ & $7.18 \mathrm{a}$ & $6.68 \mathrm{a}$ \\
$50 \%$ & $8.15 \mathrm{ab}$ & $9.65 \mathrm{ab}$ & $7.72 \mathrm{ab}$ \\
$25 \%$ & $10.92 \mathrm{bc}$ & $11.08 \mathrm{bc}$ & $8.72 \mathrm{bc}$ \\
$12.5 \%$ & $12.72 \mathrm{c}$ & $11.43 \mathrm{bc}$ & $9.12 \mathrm{bc}$ \\
$1 \%$ & $15.10 \mathrm{c}$ & $14.19 \mathrm{c}$ & $9.72 \mathrm{c}$ \\
\hline
\end{tabular}

Duncan's Multiple Range Test: Numbers followed by the same letter are not significantly different at the $5 \%$ level. Separate analyses done for each rate. 
significantly increased at each rate, by adding the fertilizer to smaller bands of soil. This table also shows that efficiency of utilization decreased at $0.4 \mathrm{gm} P$ added which indicated that the plants had reached their potential capacity to extract fertilizer $P$.

Adsorption studies conducted on the soil used in this experiment (Figure 3) indicated that increasing amounts of phosphorus remained in solution as the amount of $\mathrm{P}$ added was increased. This meant that chemically available $P$ increased as the $P$ concentration in the soil increased. Thus plant available $P$ would have been increased by applying fertilizer $P$ to smaller soil volumes, provided that uptake was not limited by plant demand. It is also possible that $P$ uptake was enhanced by greater root proliferation within the P fertilized zones as fertilized $P$ was being confined to smaller soil volumes. Strong and Soper (1974. I) found that for crops such as flax, wheat, rape and buckwheat, root development within the zone of fertilization played an important role in influencing the recovery of band-applied P. Nye (1968) also noted that for nutrients such as phosphorus, where the zone of nutrient disturbance around a single root is small, root morphology and development can be vital to the $P$ supply of the roots. Kalra (1968) on the other hand, showed that increasing the size of the treated band increased $P$ availability for flax but decreased it for rape. Thus the demand for $P$ by the crop 


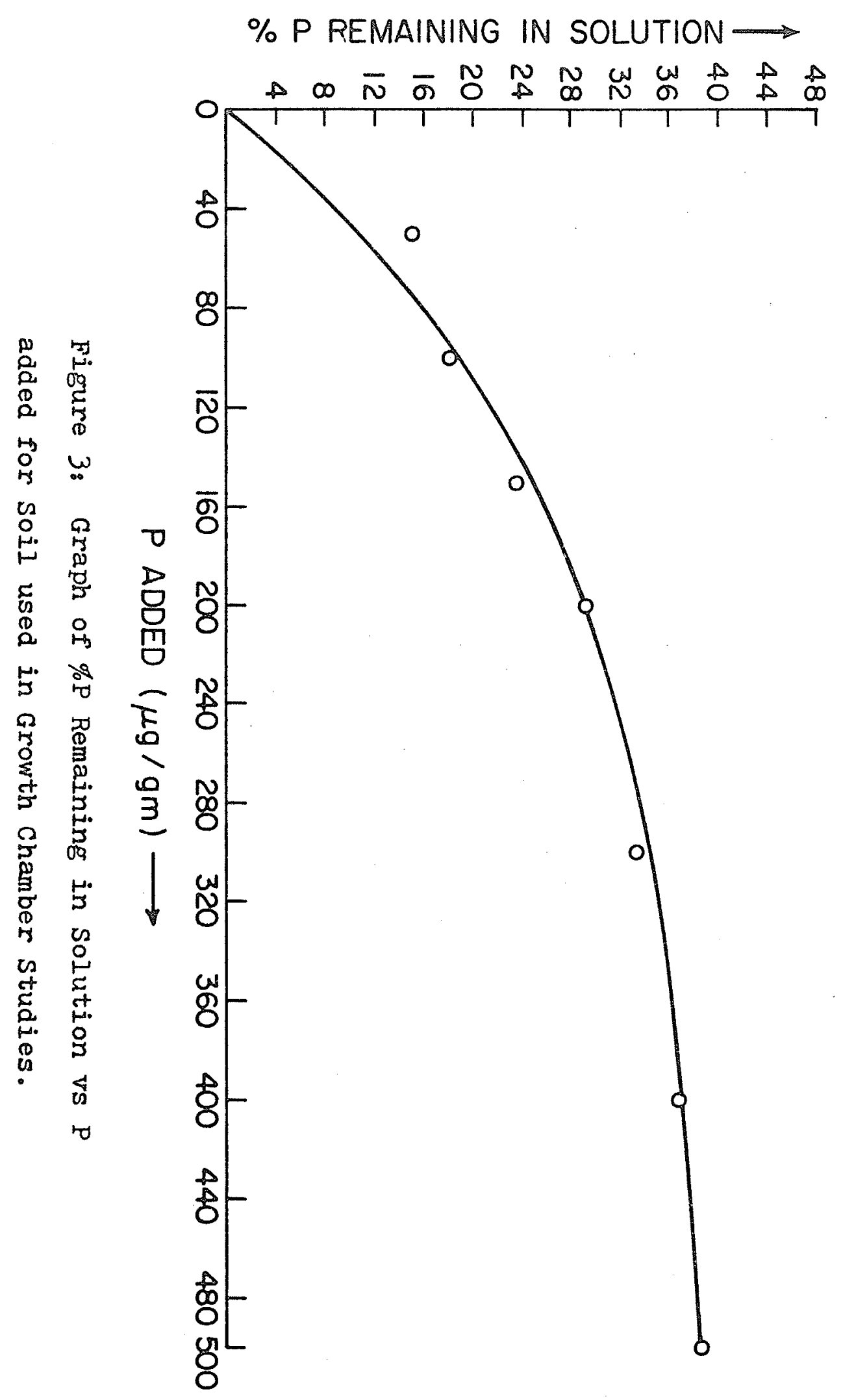


and its ability to extract $P$ from various sources are also important factors in determining $P$ uptake and response to $P$ fertilization. It would seem possible that soybeans in this experiment, behaved similar to rape i.e. being capable of some root proliferation within a zone rich in $P$ and thus extracting greater amounts of $\mathrm{P}$ from the smaller fertilizer source.

Absorption of soil phosphorus (Table 11) was enhanced by the effects of $\mathrm{P}$ fertilization on root developnent. The data shows that fertilized plants absorbed significantly higher amounts of soil $P$ than did unfertilized plants. Even though differences among those plants that were fertilized. were not significant, it was noticeable that at the lowest level of fertilization, soil $P$ absorption increased with plant size. When plant dry weight was potted against phosphorus derived from the soil (Figure 4) the latter increased with plant weight up to approximately $28 \mathrm{gm}$. Beyond this point the relationship was not linear. suggesting that the plants had reached potential soil $\mathrm{P}$ absorbing capacity. It would therefore seem that as plant size increased, the root development which ensued, permitted the exploration of larger volumes of the soil and the extraction of larger amounts of soil phosphorus.

Additional evidence in support of this contention is provided in Table 12. The "A" ratios which express the 
TABLE 11

EFFECT OF RATE OF PHOSPHORUS FERTILIZATION

AND VOLUME OF SOII TREATED ON PHOSPHORUS

DERIVED FROM SOII BY SOYBEAN PLANTS

\begin{tabular}{c|ccc}
\cline { 2 - 4 } Soil Volume Treated & \multicolumn{3}{|c}{ Phosphorus Added (gm/pot) } \\
\hline \multirow{2}{*}{$\begin{array}{c}\text { Control } \\
100 \%\end{array}$} & 0.1 & 0.2 & 0.4 \\
\hline $50 \%$ & $9.70 \mathrm{a}$ & $9.70 \mathrm{a}$ & $9.70 \mathrm{a}$ \\
$25 \%$ & $12.95 \mathrm{ab}$ & $19.11 \mathrm{~b}$ & $25.68 \mathrm{~b}$ \\
$12.5 \%$ & $14.42 \mathrm{ab}$ & $23.30 \mathrm{~b}$ & $27.17 \mathrm{~b}$ \\
$1 \%$ & $21.03 \mathrm{~b}$ & $21.43 \mathrm{~b}$ & $25.90 \mathrm{~b}$ \\
& $22.51 \mathrm{~b}$ & $24.70 \mathrm{~b}$ & $25.86 \mathrm{~b}$ \\
\hline
\end{tabular}

Duncan's Multiple Range Test: Numbers followed by the same letter are not significantly different at the 5\% level. Separate analyses done for each rate. 


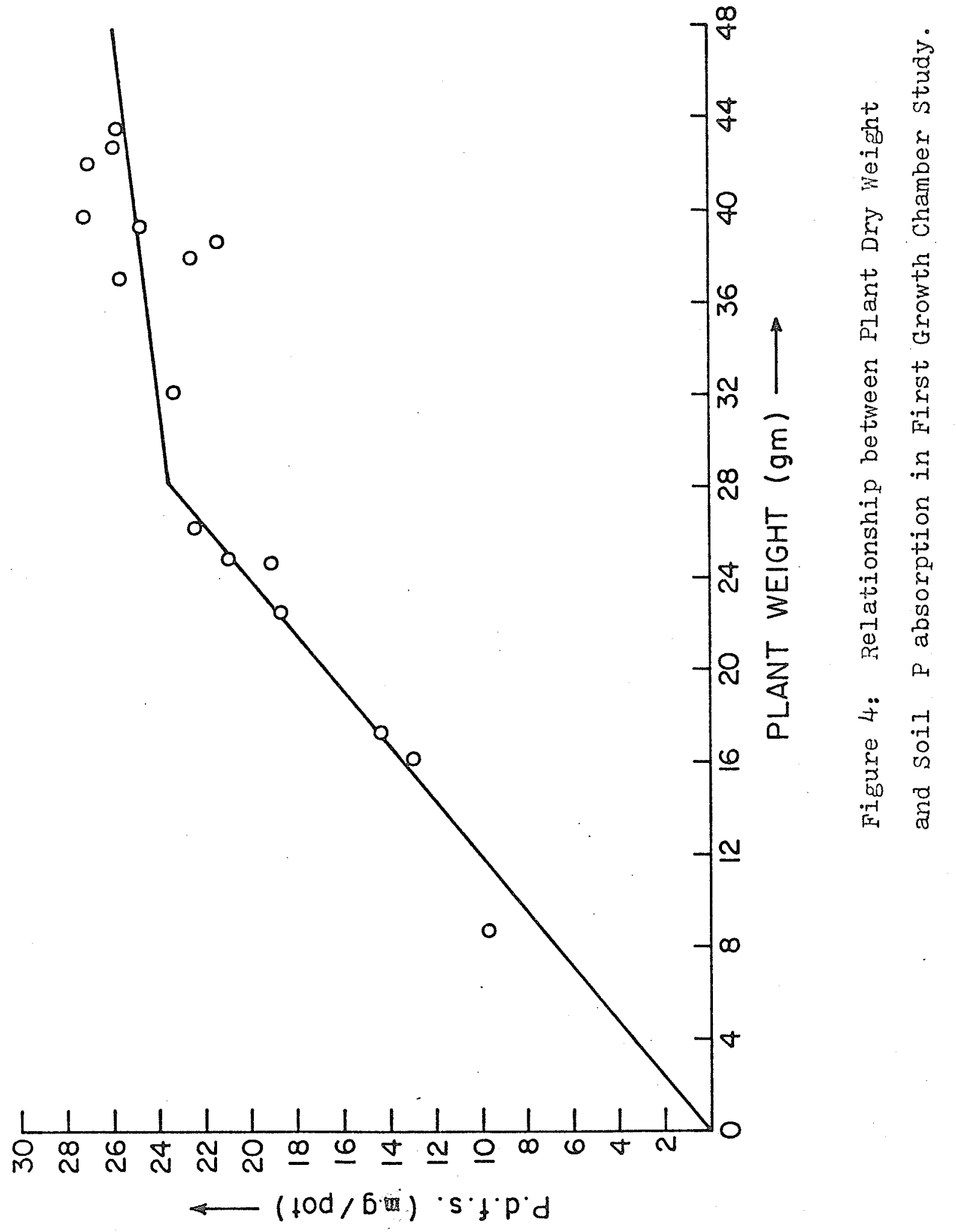


TABLE 12

CHANGE IN "A" VALUES WITH CHANGES IN AMOUNT

OF P ADDED AND VOLUME OF SOIL HHOSFHATED

\begin{tabular}{c|ccc}
\cline { 2 - 4 } Soil Volume Treated & \multicolumn{3}{|c}{ Phosphorus Added (gm/pot) } \\
\hline $100 \%$ & 0.1 & 0.2 & 0.4 \\
$50 \%$ & 185.8 & 266.0 & 384.0 \\
$25 \%$ & 176.7 & 257.5 & 352.1 \\
$12.5 \%$ & 171.4 & 213.4 & 310.1 \\
$1 \%$ & 165.3 & 183.8 & 284.0 \\
& 149.1 & 174.0 & 266.1 \\
\hline
\end{tabular}

"A" Value $=\frac{\text { Plant-P derived from Soil }}{\text { Plant-P derived from Fertilizer }} \times$ Rate of Applied $P$ All units in $\mathrm{mg} P /$ pot. 
availability of soil phosphorus relative to that of fertilizer phosphorus, increased with the amount of $P$ added. This meant that plants were extracting larger amounts of soil $P$ and/or the potentially available soil $P$ was greater as $P$ fertilization was increased. The ratios also show a decrease at each level of $P$ added with decrease in size of the treated band. Thus the availability of added $P$ was increasing when $P$ was placed in smaller fertilizer sources. Fried and Broeshart (1967) had stated that "A" values are essentially independent of the level of applied nutrient and therefore should not change with application rates. However, the effect observed here may be attributed to increased exploration of the soil phosphorus reservoir which was enhanced by phosphorus fertilization benefiting the plants and leading to larger root systems.

Over the 44-day period of growth, the plants attained an average height of $60 \mathrm{~cm}$ with some of the more responsive cases reaching as high as $72 \mathrm{~cm}$. Except for the unfertilized plants and those where $0.1 \mathrm{gm} P$ was added to $100 \%$ and $50 \%$ of the soil volume, there were no visible signs of phosphate deficiency. Deficiency symptoms showed up mainly in browning of the leaves. Tissue concentrations of $P$ (Table 13) did not increase uniformly with response to added $P$ or volume of soil phosphated. At the lowest level of $P$ fertilization. $P$ concentrations in the plant increased steadily with plant size and with total $P$ content. This was not the case at the next level. Here $P$ concentrations actually dropped as plant size increased, 


\section{TABLE 13}

PERCENT PHOSPHORUS IN SOYBEAN PLANT TISSUES AS AFFECTED

BY RATE OF PHOSPHORUS PERTILIZATION AND VOLUHE OF SOIL TREATED

\begin{tabular}{c|ccc}
\cline { 2 - 4 } & \multicolumn{3}{|c}{ Phosphorus Added (gm/pot) } \\
\hline Soil Volume Treated & 0.1 & 0.2 & 0.4 \\
\hline \multirow{2}{*}{ Control } & & $\% \mathrm{P}$ & \\
$100 \%$ & 0.111 & 0.111 & 0.111 \\
$50 \%$ & 0.122 & 0.137 & 0.141 \\
$25 \%$ & 0.128 & 0.127 & 0.146 \\
$12.5 \%$ & 0.134 & 0.115 & 0.146 \\
$1 \%$ & 0.137 & 0.115 & 0.146 \\
& 0.146 & 0.135 & 0.148 \\
\hline
\end{tabular}


pointing to a possible dilution effect. However, this trend was reversed when $0.2 \mathrm{gm} P$ was added to $1 \%$ of the soil, with $P$ concentration showing an increase. Although higher tissue concentrations were obtained with the highest level of fertilization, only a gradual increase was achieved by confining $P$ to smaller bands of soil.

Evidently the data in Table 13 does not readily lend itself to the elucidation of a critical $P$ concentration for soybeans grown in this experiment. $\% P$ in the plants reached 0.146 at the lowest level of fertilization as plant size and $P$ uptake increased. But similar percentages were found at the highest level of $P$ fertilization even though there was an obvious response to phosphorus as indicated by the increases in dry matter yields and total phosphorus uptake. 


\section{B. SECOND GROHTH CHAMBER EXPERTMENT}

The results of the first growth chamber study pointed to a capability on the part of the soybean plant, to extract greater amounts of fertilizer phosphorus when the latter was applied to smaller volumes of soil. The methods used to apply phosphorus in that experiment, would be difficult, if not impossible, to achieve by conventional commercial practice. It should be noted that even in the case where the fertilizer was applied (in solution) and mixed into the entire soil volume, that this method of application did not simulate the commercial practice of broadcasting and mixing-in pelleted or granular fertilizer. In the latter case, the fertilizer phosphorus is likely to be localized in small pockets, each constituting a concentrated fertilizer source.

Commercial farming usually utilizes a number of phosphate application methods which can be categorised as either broadcasting or banding. Hanson (1979) noted that many farmers applied band corrective and maintenance phosphorus fertilizer near the seed at planting time, in addition to broadcast treatments. Such bands are usually narrow strips and depending on the soil type, crop and fertilizer recommendation, are placed at varying distances below and away from the seed or may be applied with the seed. A third method of placement, referred to as 'Strip and Ploughed', was described by Bailey et al (1980) as being intermediate between banding and broadcasting. The 
effect of this method is to provide a high phosphorus concentration throughout a much larger soil volume than is provided for in banding, yet restricting the fertilized zone in the vicinity of the roots, as opposed to broadcasting.

Since the first study indicated that a small concentrated phosphorus fertilizer source may have been appropriate in meeting the phosphorus requirements of soybeans, it was thought that banding the fertilizer at various distances below and beside the seed would provide greater insight into the question of how best the phosphorus needs of the plant may be met. These placement methods would also more closely simulate those used in field practice.

Two placement methods for phosphorus were employed in this experiment. In one case $P$ was applied (in solution) to a narrow strip of soil at two depths below the seed and at two distances away from the seed row also at two depths below. In the second case, fertilizer $P$ was applied in the same manner as the best treatment from the first experiment i.e. sprayed on to $1 \%$ of the soil volume which was then spread as a wide band. $2.5 \mathrm{~cm}$ below the seed. This treatment was included as a means of comparing its effectiveness with that acheived by banding $P$ by the more conventional methods. In the first experiment, three levels of $P$ fertilizer application were used, with lowest levels proving to be inferior to the other two. In this case the second and third rates of application (from 
the first study) were used since it was felt that these would provide adequate amounts of phosphorus to the plants and hence the placement methods could be effectively compared.

As in the first experiment, soybean responded significantly to the addition of phosphorus on this phosphate deficient soil. Dry matter yields (Table 14) for unfertilized pots were tripled by the lowest yields achieved by $\mathrm{P}$ fertilization. There was no significant difference in dry matter yields at the lower level of $P$ application, when $P$ was added to $1 \%$ of the soil as against being banded directly below the seed. However, when the fertilized band was shifted laterally or placed at a lower depth, yields had diminished. Significant yield differences were found with fertilizer $P$ banded $5 \mathrm{~cm}$ away and $2.5 \mathrm{~cm}$ below the seed. At $5 \mathrm{~cm}$ below the seed yields were significantly reduced from where $P$ was bended $2.5 \mathrm{~cm}$ directly below. But significant increases were observed as the fertilized band was shifted $2.5 \mathrm{~cm}$ and $5 \mathrm{~cm}$ laterally at the lower depth. Statistically similar yields were obtained with $P$ banded $5 \mathrm{~cm}$ away from the seed, at both depths.

Dry matter yields at the higher level of $P$ application followed trends closely similar to those observed at the lower level. P placement in $1 \%$ of the soil resulted in yields similar to those obtained with banding $2.5 \mathrm{~cm}$ directly below the seed. Yields were decreased as the band vas laterally displaced and significantly so at $5 \mathrm{~cm}$ away. However, this trend was reversed 
TABLE 14

DRY MATTER YIELDS OF 44-DAY OLD SOYBEAN PLANTS AS AFFECTED BY RATE AND PLACEMENT OF PHOSPHORUS FERTILIZER

Dry Matter Yield (gm/pot)

Rate of Added Phosphorus

$$
\begin{aligned}
& \text { Control } \\
& 6.97 \quad \mathrm{a} \\
& \text { Wide Band placed } 2.5 \mathrm{~cm} \text { below the seed } \\
& 36.80 \\
& \text { Narrow Band placed } 2.5 \mathrm{~cm} \text { below the seed } \\
& \text { Directly Below } 2.5 \mathrm{~cm} \text { Away } 5 \mathrm{~cm} \text { Away } \\
& 0.2 \mathrm{gm} \mathrm{P} / \text { pot } 35.56 \text { d } 34.60 \text { d } 30.82 \mathrm{c} \\
& \text { Narrow Band placed } 5 \mathrm{~cm} \text { below the Seed } \\
& \begin{array}{ccc}
\text { Directly Below } 2.5 \mathrm{~cm} \text { Away } & 5 \mathrm{~cm} \text { Away } \\
21.62 & \mathrm{~b} & 26.60 \mathrm{C}
\end{array} \\
& \text { Wide Band placed } 2.5 \mathrm{~cm} \text { below the seed } \\
& 41.67 \\
& \text { Narrow Band placed } 2.5 \mathrm{~cm} \text { below the seed } \\
& 0.4 \mathrm{gm} P / \text { pot } \\
& \text { Directly Below } 2.5 \mathrm{~cm} \text { Away } 5 \mathrm{~cm} \text { Away } \\
& \text { Narrow Band placed } 5 \mathrm{~cm} \text { below the seed } \\
& \text { Directly Below } 2.5 \mathrm{~cm} \text { Away } 5 \mathrm{~cm} \text { Away } \\
& 27.16 \text { b } 31.96 \text { c } 33.04 \mathrm{~cd} \\
& \text { Control } \\
& 6.97 \quad \text { a }
\end{aligned}
$$

Duncan's Multiple Range Test: Numbers followed by the same letter are not significantly different at the $5 \%$ level. Separate analyses done for each rate used. 
with $P$ placement at $5 \mathrm{~cm}$ below the seed. The lowest yield for fertilized plants was found where $P$ was banded $5 \mathrm{~cm}$ directly below the seed and this was significantly increased when the band was placed $2.5 \mathrm{~cm}$ and $5 \mathrm{~cm}$ away. An almost constant yield difference of 4 to $6 \mathrm{gm}$ was maintained between the two rates of $P$ application, regardless of placement. This difference was similar to that obtained in the first experinent when $P$ was applied to $1 \%$ of the soil.

The response to $P$ fertilization was also significant in terms of total $P$ uptake (Table 15). A pattern similar to that observed in the dry matter yield data, emerged. P uptake in the unfertilized pots was essentially tripled by that achieved in the worst of the fertilized treatments. With $0.2 \mathrm{gm} P$ added per pot, total $P$ uptake was not significantly different when $P$ was added to $1 \%$ of the soil, or banded $2.5 \mathrm{~cm}$ directly below or $2.5 \mathrm{~cm}$ away from the seed. At this depth however, P uptake decreased significantly as the band was placed $5 \mathrm{~cm}$ away. Uptake was reduced significantly when the fertilized band was placed directly below the seed at $5 \mathrm{~cm}$, but increased as this band was shifted $2.5 \mathrm{~cm}$ and $5 \mathrm{~cm}$ away. With increased fertiIization the trend in total $P$ uptake was similar, although no significant differences were found with banding at $5 \mathrm{~cm}$ deep whether the band was directly below or away from the seed. The most dramatic effect of the various placement methods used was the difference in $P$ uptake effected by placing the smaller 


\section{TABLE 15}

TOTAL PHOSPHORUS UPTAKE BY 44-DAY OLD SOYBEAN PLANTS

AS AFFECTED BY RATE AND PLACEMENT OF FERTILIZER PHOSPHO RUS

Total P Uptake ( $\mathrm{mg} / \mathrm{pot})$

Rate of Added Phosphorus

Control

9.84 a

Wide Band placed $2.5 \mathrm{~cm}$ below the seed 58.76

$0.2 \mathrm{gm} F /$ pot Narrow Band placed $2.5 \mathrm{~cm}$ below the Seed

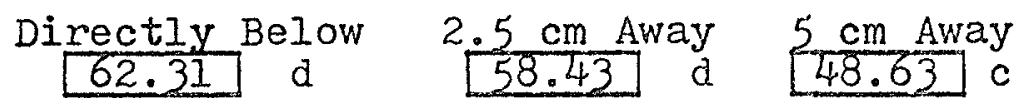
Narrow Band placed $5 \mathrm{~cm}$ below the seed Directly Below
$[39.49]$

Wide Band placed $2.5 \mathrm{~cm}$ below the seed 68.62

Narrow Band placed $2.5 \mathrm{~cm}$ below the seed

$0.4 \mathrm{gm} \mathrm{P} /$ pot

Directly Below $2.5 \mathrm{~cm}$ Away
$[1.64 \mathrm{~cm}$ Away

Narrow Band placed $5 \mathrm{~cm}$ below the seed

Directly Below $2.5 \mathrm{~cm}$ Away $5 \mathrm{~cm}$ Away 48.08 b 50.04 b 51.85 b

Control

$9.84 \quad \mathrm{a}$

Duncan's Multiple Range Test: Numbers followed by the same letter are not significantly different at the $5 \%$ level. Separate analyses done for each rate used. 
band $5 \mathrm{~cm}$ directly below as against placement $2.5 \mathrm{~cm}$ directly below. Total phosphorus uptake decreased by $36 \%$ and $33 \%$ for the lower and higher rates of $P$ application respectively, when $P$ was placed at the lower depth. Considering that the effective concentration of fertilizer phosphorus would have been similar at either depth, the results point to greater positional availability of phosphorus with placement at $2.5 \mathrm{~cm}$ directly below the seed.

The responses to band application of phosphorus so far noted in this study, are further clarified by the data presented in Table 16. At both levels of fertilization plants were extracting significantly higher amounts of $P$ from the fertilizer source when this was placed $2.5 \mathrm{~cm}$ below the seed as against being placed in $1 \%$ of the soil volume. The former placement represented the best treatment used in terms of phosphorus derived from fertilizer. At the lower rate of $P$ application, significantly less $P$ was fertilizer derived when $P$ was banded $2.5 \mathrm{~cm}$ deep and $2.5 \mathrm{~cm}$ away. Uptake of fertilizer $P$ here was also significantly higher than where the band was placed $5 \mathrm{~cm}$ saway. Fertilizer $\mathrm{P}$ uptake also decreased by more than half when the band was moved from $2.5 \mathrm{~cm}$ directly below to $5 \mathrm{~cm}$ in the same lateral position. Increasing the rate of $P$ fertilization resulted in increased fertilizer $P$ uptake but the trend remained similar. placement $2.5 \mathrm{~cm}$ directly below the seed proved to be significantly better than all other 
TABLE 16

EFFECT OF RATE AND PLACEMENT OF FERTIIIZER PHOSPHORUS

ON PHOSPHORUS DERIVED FROM FERTILIZER

BY 44-DAY OLD SOYBEAN PLANTS

$$
\text { P.d.f.r. (mg/pot) }
$$

Rate of Added Phosphorus

Wide Band placed $2.5 \mathrm{~cm}$ below the seed 30.99

$0.2 \mathrm{gm} \mathrm{P} /$ pot Narrow Band placed $2.5 \mathrm{~cm}$ below the seed

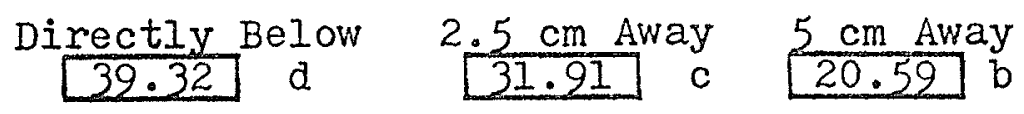
Narrow Band placed $5 \mathrm{~cm}$ below the seed Directly Below $2.5 \mathrm{~cm}$ Away $5 \mathrm{~cm}$ Away [15.11 a 18.88 ab 21.55 b

Wide Band placed $2.5 \mathrm{~cm}$ below the seed 43.17

$0.4 \mathrm{gm} \mathrm{P} /$ pot Narrow Band placed $2.5 \mathrm{~cm}$ below the Seed \begin{tabular}{cc} 
Directly Below \\
$50.29 \mathrm{~cm}$ away & $5 \mathrm{~cm}$ Away \\
\hline 58.68 b & 26.47 a
\end{tabular} Narrow Band placed $5 \mathrm{~cm}$ below the seed \begin{tabular}{ccc} 
Directly Below & $2.5 \mathrm{~cm}$ Away & $5 \mathrm{~cm}$ Away \\
\hline 21.82 & a & 24.40
\end{tabular}

Duncan's Multiple Range Test: Numbers followed by the same letter are not significantly different at the 5\% level. Separate analyses done for each rate used. 
methods, with fertilizer $P$ uptake here again doubling that achieved when $P$ was banded at the $5 \mathrm{~cm}$ depth. Displacement of the band laterally to $2.5 \mathrm{~cm}$ and $5 \mathrm{~cm}$ produced significant differences in fertilizer $P$ uptake at the lower depth.

The efficiency of $P$ fertilizer utilization was significantly improved by placement $2.5 \mathrm{~cm}$ directly below the seed. over all other methods (Table 17). It is of interest to note that with $P$ applied to $1 \%$ of the soil volume, fertilizer use efficiency in this experiment showed little change from the levels achieved at similar $P$ application rates in the first experiment. These efficiencies were also similar at the respective application rates to those achieved by sidebanding $P 2.5 \mathrm{~cm}$ below and $2.5 \mathrm{~cm}$ away from the seed. Placement of P $2.5 \mathrm{~cm}$ directly below the seed resulted in the highest percentage utilization of fertilizer $P$, at both rates of $P$ fertilization. Plants with $0.2 \mathrm{gm} P$ added in this manner, derived $63 \%$ of their total P supply from fertilizer $P$ while with 0.4 gm $P$ added, up to $70 \%$ of total plant $P$ was fertilizer derived.

The observed sensitivity of this soybean cultivar to the placement of phosphorus fertilizer may be partly attributed to the development of the plant's root system. Root systems that recover a large proportion of applied nhosphorus have been found to proliferate more extensively within the fertilizer reaction zone than roots of crops that recover only small amounts of applied phosphorus (Strong and soper, 1974 I and II). 


\section{TABLE 17}

PERCENTAGE UTILIZATION OF FERTILIZER PHOSPHORUS BY 44-DAY OLD SOYBEAN PLANTS AS AFFECTED BY RATE AND PLACEMENT OF FERTILIZER PHOS PHORUS

$\%$ Utilization

Rate of Added Phosphorus

Wide Band placed $2.5 \mathrm{~cm}$ below the seed

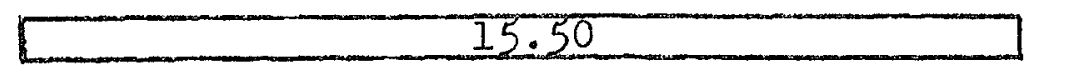

c

$0.2 \mathrm{gm} \mathrm{P} /$ pot Narrow Band placed $2.5 \mathrm{~cm}$ below the Seed $\begin{array}{ccc}\text { Directly Below } 2.5 \mathrm{~cm} \text { Away } & 5 \mathrm{~cm} \text { Away } \\ 19.66 & \mathrm{~d} & 15.96 \\ \end{array}$

Narrow Band placed $5 \mathrm{~cm}$ below the seed \begin{tabular}{cc} 
Directly Below & $2.5 \mathrm{~cm}$ Away \\
\hline $.56{ }^{3} \mathrm{~cm}$ Away \\
\hline 2.55 ab
\end{tabular}

Wide Band placed $2.5 \mathrm{~cm}$ below the seed 10.79

$\mathrm{b}$ $0.4 \mathrm{gm} \mathrm{P} /$ pot

Narrow Band placed $2.5 \mathrm{~cm}$ below the seed \begin{tabular}{c} 
Directly Below $2.5 \mathrm{~cm}$ Away $5 \mathrm{~cm}$ Away \\
\hline 12.57 c
\end{tabular} Narrow Band placed $5 \mathrm{~cm}$ below the seed Directly Below $2.5 \mathrm{~cm}$ Away $5 \mathrm{~cm}$ Away
5.46 a

Duncan's Multiple Range Test: Numbers followed by the same letter are not significantly different at the $5 \%$ level. Separate analyses done for each rate used. 
In this experiment however, the banded $P$ fertilizer sources were placed at various locations relative to the seed but $P$ concentrations were similar at the respective rates of application. Thus it would be expected that $\mathrm{P}$ availability within each reaction zone would have been similar and that roots would have proliferated to the same extent within each zone. It is therefore likely that the pattern of root growth within the pots could have accounted, in part, for the observed differences in $P$ uptake.

Since phosphorus is relatively immobile in soils, plant roots extend towards the source of phosphorus as they grow into the soil. P placement directly below the seed would seem to benefit the plant provided that the depth of placement is within reach of the primary roots and that the application rates are not injurious to the seedling plant. Phosphorus sources placed away from the seed would tend to be utilized as the roots grow laterally. Thus uptake from these sources over an entire growth period would be less than uptake from the source directly below the seed since exploration of the latter source would commence earlier.

Utilization of soil phosphorus in this experiment did not vary greatly with placement of fertilizer phosphorus (Table 18). As in the first experiment, P fertilization resulted in a significant increase in soil $\mathrm{P}$ absorption. Among the fertilized plants, soil $\mathrm{P}$ absorption was least where $\mathrm{P}$ 


\section{TABLE 18}

\section{EFFECT OF RATE AND PLACEMENT OF FERTILIZER PHOS PHORUS}

ON PHOSPHORUS DERIVED FROM SOIL BY 44-DAY OLD SOYBEAN FLANTS

$$
\text { P.d.f.s. (mg/pot) }
$$

Rate of Added Phosphorus

Control

$9.84 a$

Wide Band placed $2.5 \mathrm{~cm}$ below the seed 27.77

bc

Narrow Band placed $2.5 \mathrm{~cm}$ below the seed

Directly Below

22.66

$2.5 \mathrm{~cm}$ Away

$5 \mathrm{~cm}$ Away

$0.2 \mathrm{gm} \mathrm{P} / \mathrm{pot}$

Narrow Band placed $5 \mathrm{~cm}$ below the seed

Directly Below

24.38 bc

$2.5 \mathrm{~cm}$ Away

24.30 bc 25.58 bc

Wide Band placed $2.5 \mathrm{~cm}$ below the seed 25.45

$c$

$0.4 \mathrm{gm} \mathrm{P} / \mathrm{pot}$

$$
\begin{aligned}
& \begin{array}{c}
\text { Directly Below } \\
21.52 \mathrm{~cm} \text { Away } \\
21.24 \mathrm{~cm} \text { Away } \\
29.27 \mathrm{c}
\end{array} \\
& \text { Narrow Band placed } 5 \mathrm{~cm} \text { below the seed } \\
& \begin{array}{ccc}
\text { Directly Below } & 2.5 \mathrm{~cm} \text { Away } \\
26.26 & \mathrm{~cm} \text { Away } & \\
25.63 & \mathrm{c} &
\end{array} \\
& \text { Control } \\
& 9.84 a
\end{aligned}
$$

Duncan's Multiple Range Test: Numbers followed by the same letter are not significantly different at the $5 \%$ level. 
was placed $2.5 \mathrm{~cm}$ directly below the seed and highest where $P$ was banded $2.5 \mathrm{~cm}$ below and $5 \mathrm{~cm}$ away. This was observed at both levels of $\mathrm{P}$ application.

In the first experiment, soil $P$ absorption was shown to increase with plant size up to the point where the plants had attained a dry weight of approximately $28 \mathrm{gm}$ (see Figure 4). In this study, except for the control pots, there was no apparent relationship between plant dry weights and soil $P$ absorption. This may have been due to the fact that the two rates of $P$ fertilization used here resulted in plants of almost similar sizes with dry weights mostly above $28 \mathrm{gm}$. The plants here were generally larger than in the first experiment and it is likely that the root systems were more capable of exploring the soil p reservoir.

Phosphorus content of the plant tissues (Table 19) reflected the effects of $P$ fertilization but did not vary greatly with placement of $P . \quad P$ content for unfertilized plants was similar to that obtained in the first experiment. As in the first study plants in the control pots showed phosphate deficiency symptoms - mainly as leaf browning. With p fertilization, $P$ content of the tissues was considerably increased. At the lower level of fertilization the best results were found where $P$ was placed $5 \mathrm{~cm}$ directly below the seed. This may have been due to relatively small amounts of dry matter produced with this treatment since plants in this category also absorbed the least phosphorus among those that received $P$ 
TABLE 19

\section{PERCENT PHOSPHORUS IN PLANT TISSUE OF 44-DAY OLD \\ SOYBEAN PLANTS AS AFFECTED BY RATE AND \\ PLACEMENT OF FERTILIZER PHOSPHORUS}

$\% \mathrm{P}$

Rate of Added Phosphorus

Control

0.115

Wide Band placed $2.5 \mathrm{~cm}$ below the seed

$0.2 \mathrm{gm} \mathrm{P} /$ pot $\begin{array}{cc}\text { Directly Below } \\ 0.172 & 2.5 \mathrm{~cm} \text { Away } \\ 0.171 & 5 \mathrm{~cm} \text { Away } \\ 0.158\end{array}$
Narrow Band placed $5 \mathrm{~cm}$ below the seed

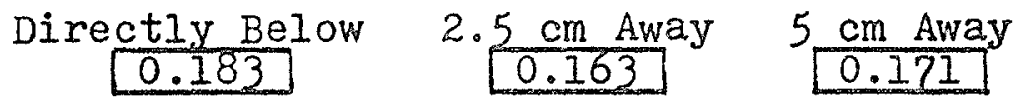

Wide Band placed $2.5 \mathrm{~cm}$ below the Seed

0.165

Narrow Band placed $2.5 \mathrm{~cm}$ below the seed

$0.4 \mathrm{gm} \mathrm{P} /$ pot

$\begin{array}{ccc}\text { Directly Below } & 2.5 \mathrm{~cm} \text { Away } & 5 \mathrm{~cm} \text { Away } \\ 0.182 & 0.174 & 0.163\end{array}$

Narrow Band placed $5 \mathrm{~cm}$ below the seed $\begin{array}{ccc}\text { Directly Below } & 2.5 \mathrm{~cm} \text { Away } & 5 \mathrm{~cm} \text { Away } \\ 0.172 & 0.152 & 0.157\end{array}$ Control 0.115 
fertilizer. At the higher level of $P$ fertilization, $P$ tissue content was greatest where $P$ was placed $2.5 \mathrm{~cm}$ directly below the seed. This treatment also represented the highest total $P$ uptake and the second highest dry matter yield.

Phosphorus application to $1 \%$ of the soil resulted in increased $P$ content of the plants compared with the same treatments in the first experiment. Plants with $0.2 \mathrm{gm} P$ applied per pot had a tissue concentration of $0.160 \% \mathrm{P}$ compared with $0.135 \% \mathrm{P}$ in the first study. Similarly, with $0.4 \mathrm{gm} P$ applied, tissue concentration was $0.165 \% \mathrm{P}$ compared with $0.148 \%$ $P$ obtained in the first experiment. An explanation for this disparity is not imminent since in both experiments, dry matter yields and total $P$ uptake from the respective fertilizer treatments were comparably high. 


\section{FIELD EXPERIMENTS}

\section{Phosphorus Placement Study}

The two growth chamber experiments discussed, provided information on the phosphorus uptake characteristics of the soybean plant, expecially as they relate to the placement of phosphorus fertilizer. The application methods used in those studies are not easily simulated in field experiments. Field conditions also, do not provide the facility of a controlled environment. Field experimentation is however, useful and often necessary in further investigating the conclusions that may have been drawn from growth chamber studies.

A field study was undertaken at two sites in Manitoba in the summer of 1979, with the objective of providing further information on the role of phosphorus fertilizer placement in illiciting responses to $P$ application by soybeans. Since it was evident from the growth chamber studies that placement of phosphorus was of prime importance to soybean response to $P_{0}$ a number of placement methods were tested. The methods used, fall under the two broad categories of broadcasting and banding. Broadcast applications of phosphorus involve the uniform distribution of the fertilizer over the soil surface and this may be followed by shallow and deep cultivation. It is intended to provide a condition in which the concentration of applied $P$ is relatively even in a specific volume of soil. In this experiment broadcast applications of $P$ were effected in the 
previous Fall and in the spring of 1979. The fertilizer was worked into the soil by shallow cultivation.

Band application of $P$ is used to provide the plant with a more concentrated source of fertilizer $P$ at a prescribed position in relation to the seed. Three methods of banding were used in this experiment: (1) seed placement - the fertilizer was placed in direct contact with the seed. This method was successfully used when $P$ application rates did not exceed levels that caused seed injury or delayed emergence (Hoeft et al 1975; Miller et al 1971). (2) Sidebanding here fertilizer $P$ was placed $2.5 \mathrm{~cm}$ below and $2.5 \mathrm{~cm}$ away from the seed. This is often done when higher $P$ application rates are required. (3) Placement directly below the seed fertilizer $P$ was placed $2.5 \mathrm{~cm}$ directly below the seed row. This method of application is generally more difficult to achieve in the field and in this case, required the use of a specially designed machine which combined both seeding and fertilizing operations. In the growth chamber studies, this placement method was shown to be the most effective of those used, in supplying phosphorus to soybeans.

In addition to various placement methods, rate of applis cation was also varied. Rates of up to $120 \mathrm{~kg} \mathrm{P}_{2} \mathrm{O}_{5}$ / ha were used on phosphate deficient soils with test levels of 4.8 and $4.3 \mathrm{~kg} \mathrm{P} / \mathrm{ha}\left(\mathrm{NaHCO}_{3}\right.$ extractable). The two soils also differed in texture - sandy soil at Brandon and a clay soil at Neepawa. 
The experiment was therefore designed to provide information on soybean response to $\mathrm{P}$ placement methods, rate of $\mathrm{P}$ fertilization as well as how these varied with soil type.

At both sites differences due to $P$ fertilizer placement as well as any differences attributable to $P$ fertilization. did not become apparent until the flowering stage (Tables 20 and 21). From there on, significantly higher dry matter yields were achieved with banding as against broadcasting $P$. Seedplaced $P$ fertilizer, however, resulted in reduced yields when used at the highest rate: this effect being evident at both sites even at earliest harvest. Observations in the field showed that this was primarily due to reduced seedling emergence. Hoeft et al (1975) found that soybeans planted on a silt loam soil experienced reduced and delayed emergence when phosphorus fertilization exceeded $10.2 \mathrm{~kg}$ P/ha of seed-placed P. This study found that dry matter yield continued to increase up to a rate of $12 \mathrm{~kg} \mathrm{P} / \mathrm{ha}$ similarly placed but drastiw cally reduced at a rate of $26.2 \mathrm{~kg} \mathrm{P} / \mathrm{ha}$.

The broadcast treatments produced little or no response to $P$ fertilization in terms of dry matter yield. In fact, dry matter yields with these treatments only exceeded those on the control plots when the rate of fertilization was greater than $20 \mathrm{~kg} \mathrm{P}_{2} \mathrm{O}_{5} / \mathrm{ha}$. Even so, increases were inconsistent and the differences not statistically significant. On the other hand, banding of the fertilizer did produce significant yield 
TABLE 20

DRY MATTER YIELDS OF FIELD GROWN SOYBEANS, AT THREE GROWTH STAGES, AS AFFECTED BY RATE AND PLACEMENT OF PHOSPHORUS FERTILIZER

Brandon site



Duncan's Multiple Range Test: Numbers followed by the same

letter are not significantly different at the $5 \%$ level.

Separate analyses done for each rate used. 
DRY MATTER YIELDS OF FIELD GROWN SOYBEANS, AT THREE GROWTH STAGES, AS AFFECTED BY RATE AND PLACEMENT OF PHOS PHORUS FERTILIZER

Neepawa Site

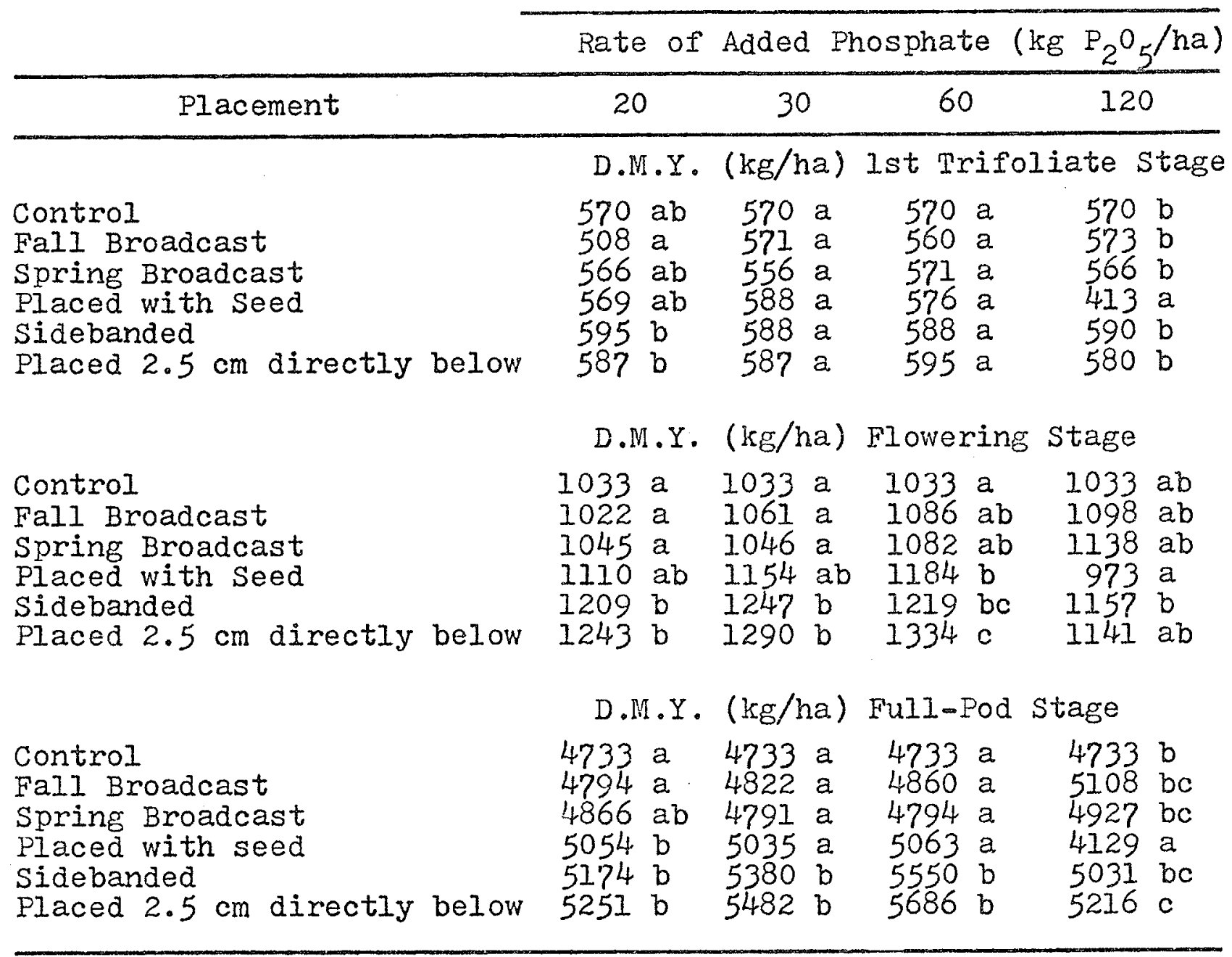

Duncan's Multiple Range Test: Numbers followed by the same letter are not significantly different at the 5\% level. Separate analyses done for each rate used. 
increases. At all stages, except at maturity, sidebanding at $2.5 \mathrm{~cm}$ below and $2.5 \mathrm{~cm}$ away from the row, resulted in dry matter yields comparable to those achieved with placement directly below the seed row. These were also consistent yield increases with the placements, with increase in fertilization rate up to $60 \mathrm{~kg} \mathrm{P}_{2} \mathrm{O}_{5} / \mathrm{ha}$. The highest rate however, resulted in somewhat decreased dry matter yields at both sites and all stages of growth. Only in the case of the seed-placed fertilization was such yield reduction attributed to reduced emergence.

While the pattern of dry matter production as this related to $P$ placement and rate, was quite similar at the two sites, the rate of dry matter accumulation differed appreciably after the first trifoliate stage. At Brandon, dry matter accumulated at an average rate of $14 \mathrm{~kg} / \mathrm{ha} /$ day during the first growth phase while at Neepawa the comparable figure was $15 \mathrm{~kg} /$ ha/day. For the second and third stages, the rate at Brandon had increased $97 \mathrm{~kg} / \mathrm{ha} /$ day and $212 \mathrm{~kg} / \mathrm{ha} /$ day respectively and at Neepawa the average rate for the same periods were $50 \mathrm{~kg} /$ ha/day and $176 \mathrm{~kg} / \mathrm{ha} /$ day. The overall growth pattern of the crop, was nevertheless, similar, with the period of greatest activity occurring between the flowering and full-pod stages. Hanway and Weber (1971) also found that maximum accumulation rates for most soybean plant parts occurred between 56 and 84 days which also corresponded to the period of greatest $P$ 
absorption.

The differences in dry matter accumulation rates at the two sites may have been partially attributable to rainfall pattern experienced at the two sites. Table 4 shows a more equitable rainfall distribution at Neepawa over the four month period. While both sites received adequate rainfall in Nay (at planting) the latter three months were relatively dry at Brandon. Rainfall in July al though comparable to June, came at Brandon, in the form of one or two heavy downpours. This may have resulted in some compensatory growth at this site, accounting for the larger increases in dry matter accumulation rates.

Although dry matter yields at Brandon were higher than at Neepawa by the full-pod stage, these were not reflected in similarly higher grain yields. On the contrary, Table 22 shows that the Neepawa plots gave higher grain yields overall. However, the effects of the fertilizer placement methods were similar at both sites. Band applications resulted in significantly higher seed yields than broadcast applications. Of the three methods used in banding, placement directly below the seed row proved to be superior especially at rates of 30 and $60 \mathrm{~kg} \mathrm{P} \mathrm{P}_{5} / \mathrm{ha}$. At the latter rate of application, placement below the seed row increased yields by $62 \%$ at Brandon and $44 \%$ at Neepawa over the combined average for the two broadcast methods. Grain yields also increased steadily with rate of 
TABLE 22

GRAIN YIEUDS OF FIELD GROWN SOYBEANS AS AFFECTED

BY RATE AND PLACENENT OF PHOSPHORUS FE ZTIIIIZER

Brandon Site

\begin{tabular}{|c|c|c|c|c|}
\hline & \\
\hline & \multicolumn{4}{|c|}{ Rate of Added Phosphate $\left(\mathrm{kg} \mathrm{P}_{2} \mathrm{O}_{5}\right.$} \\
\hline Placement & 20 & 30 & 60 & 120 \\
\hline & \multicolumn{4}{|c|}{ Grain Yield (kg/ha) } \\
\hline Control & $1153 \mathrm{a}$ & $1153 \mathrm{a}$ & 1153 a & $1153 \mathrm{ab}$ \\
\hline Fall Broadcast & 1048 a & $1121 \mathrm{a}$ & $1150 \mathrm{a}$ & $1200 \mathrm{~b}$ \\
\hline Spring Broadcast & $1069 \mathrm{a}$ & $1104 \mathrm{a}$ & $1176 \mathrm{a}$ & $1237 \mathrm{~b}$ \\
\hline Placed with seed & $1353 \mathrm{~b}$ & $1401 \mathrm{~b}$ & $1526 \mathrm{~b}$ & $1087 \mathrm{a}$ \\
\hline Sidebanded & $1395 \mathrm{~b}$ & $1446 \mathrm{~b}$ & $1619 \mathrm{~b}$ & $1685 \mathrm{c}$ \\
\hline \multirow[t]{3}{*}{ Placed $2.5 \mathrm{~cm}$ directly below } & $1437 \mathrm{~b}$ & $1567 \mathrm{c}$ & $1890 \mathrm{c}$ & $1743 \mathrm{c}$ \\
\hline & a site & & & \\
\hline & \multicolumn{4}{|c|}{ Grain Yield ( $\mathrm{kg} / \mathrm{ha})$} \\
\hline Control & $1325 \mathrm{a}$ & $1325 \mathrm{a}$ & $1325 \mathrm{a}$ & $1325 \mathrm{a}$ \\
\hline Fall Broadcast & $1338 \mathrm{a}$ & 1381 a & 1358 a & 1418 a \\
\hline Spring Broadcast & $1322 \mathrm{a}$ & 1351 a & $1394 \mathrm{a}$ & $1439 \mathrm{a}$ \\
\hline Placed with seed & $1478 \mathrm{~b}$ & $1575 \mathrm{~b}$ & $1579 \mathrm{~b}$ & $1438 \mathrm{a}$ \\
\hline Sidebanded & $1547 \mathrm{bc}$ & $1629 \mathrm{~b}$ & $1847 \mathrm{c}$ & $1788 \mathrm{~b}$ \\
\hline Placed $2.5 \mathrm{~cm}$ directly below & $1622 \mathrm{c}$ & $1755 \mathrm{c}$ & $1987 \mathrm{~d}$ & $1912 \mathrm{c}$ \\
\hline
\end{tabular}

Duncan's Multiple Range Test: Numbers followed by the same letter are not significantly different at the 5\% level. Separate analyses done for each rate used. 
$P$ application up to $60 \mathrm{~kg} \mathrm{P}_{2} \mathrm{O}_{5} / \mathrm{ha}$, for all placement methods at both sites. At $120 \mathrm{~kg} \mathrm{P}_{2} \mathrm{O}_{5} /$ ha however, yields were either depressed or showed no appreciable increase. This would indicate that the highest rate of application used here, exceeded the fertilization rate of optimum grain production.

Rainfall and soil conditions may have also affected total $P$ uptake at various stages of growth. Tables 23 and 24 give the data for total P uptake by plants at the two sites. Differences in uptake due to P-placements were much greater at the Brandon site as shown by the statistical analysis. Thus placement of phosphorus may have been more critical on the sandy soil than on the clay soil in terms of $P$ uptake by the plants. It is also clear that the rate of $F$ uptake at the two sites differed appreciably between the first and second harvests. The rate of phosphorus accumulation for that period was $0.382 \mathrm{~kg} \mathrm{P} / \mathrm{ha} /$ day at Brandon and $0.223 \mathrm{~kg} \mathrm{P} / \mathrm{ha} /$ day at Neepawa. This may have been due to the increased growth rate at the Brandon site which resulted from rainfall occurring at that time.

The results show that $P$ uptake was significantly greater with $P$ fertilizer placed directly below the seed row than with any other placement. This was especially so at the Brandon site where significant differences in uptake were apparent even at the stage of the first harvest. At Neepawa where differences were less sharp, some were nevertheless observed at the higher 


\section{TABLE 23}

TOTAL PHOSPHORUS UPTAKE BY FIELD GROWN SOYBEANS AT THREE GROWTH STAGES, AS AFFECTED BY RATE AND PLACEMENT OF PHOS PHORUS FERT ILIZER

Brandon Site

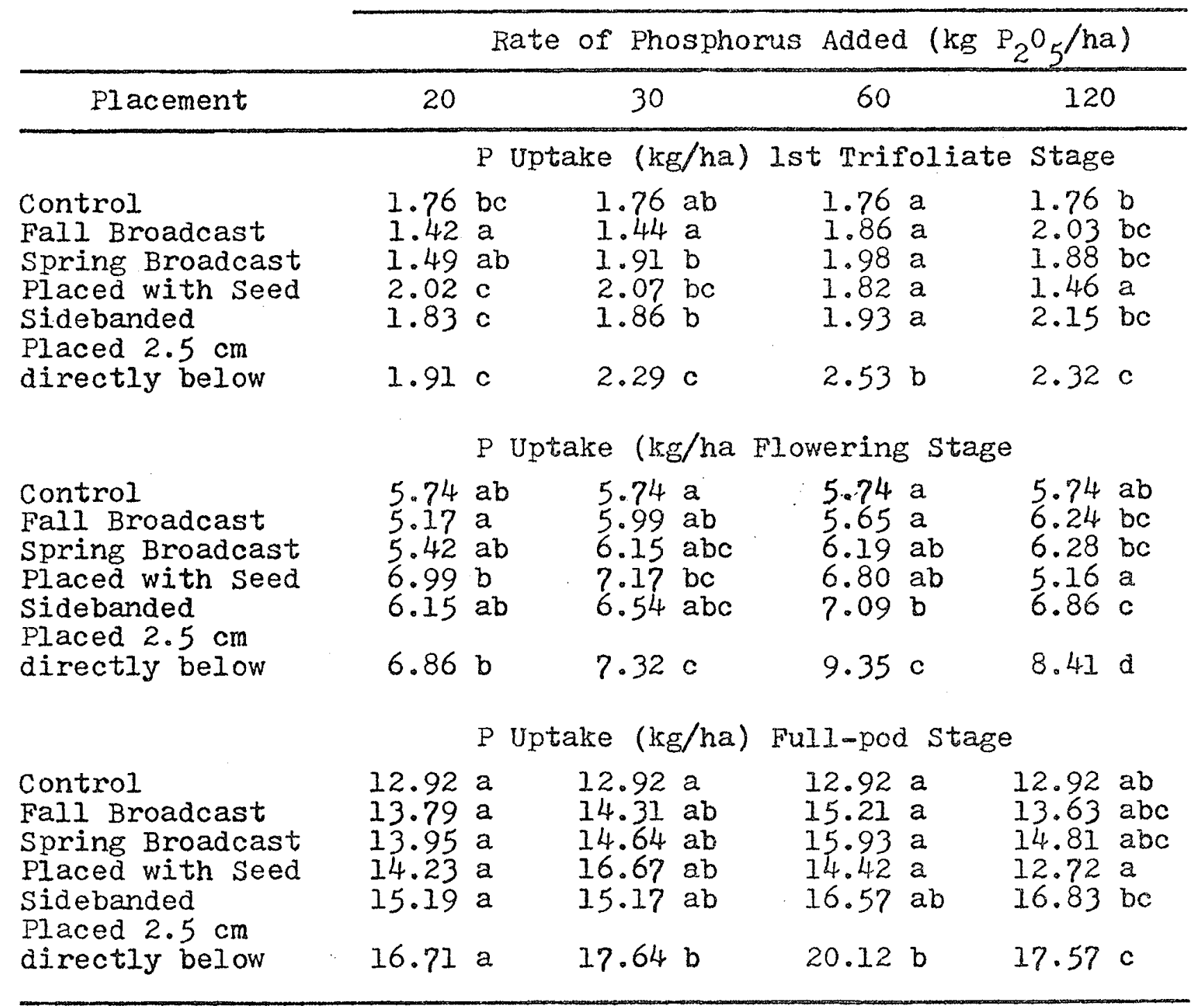

Duncan's Multiple Range Test: Numbers followed by the same letter are not significantly different at the $5 \%$ level. Separate analyses done for each rate used. 
TABLE 24

TOTAL PHOSPHORUS UPTAKE BY FIELD GROWN SOYBEANS AT THREE GROWTH STAGES, AS AFFECTED BY RATE AND PLACEVENT OF PHOSPHORUS FERT ILIZER

Neepawa site

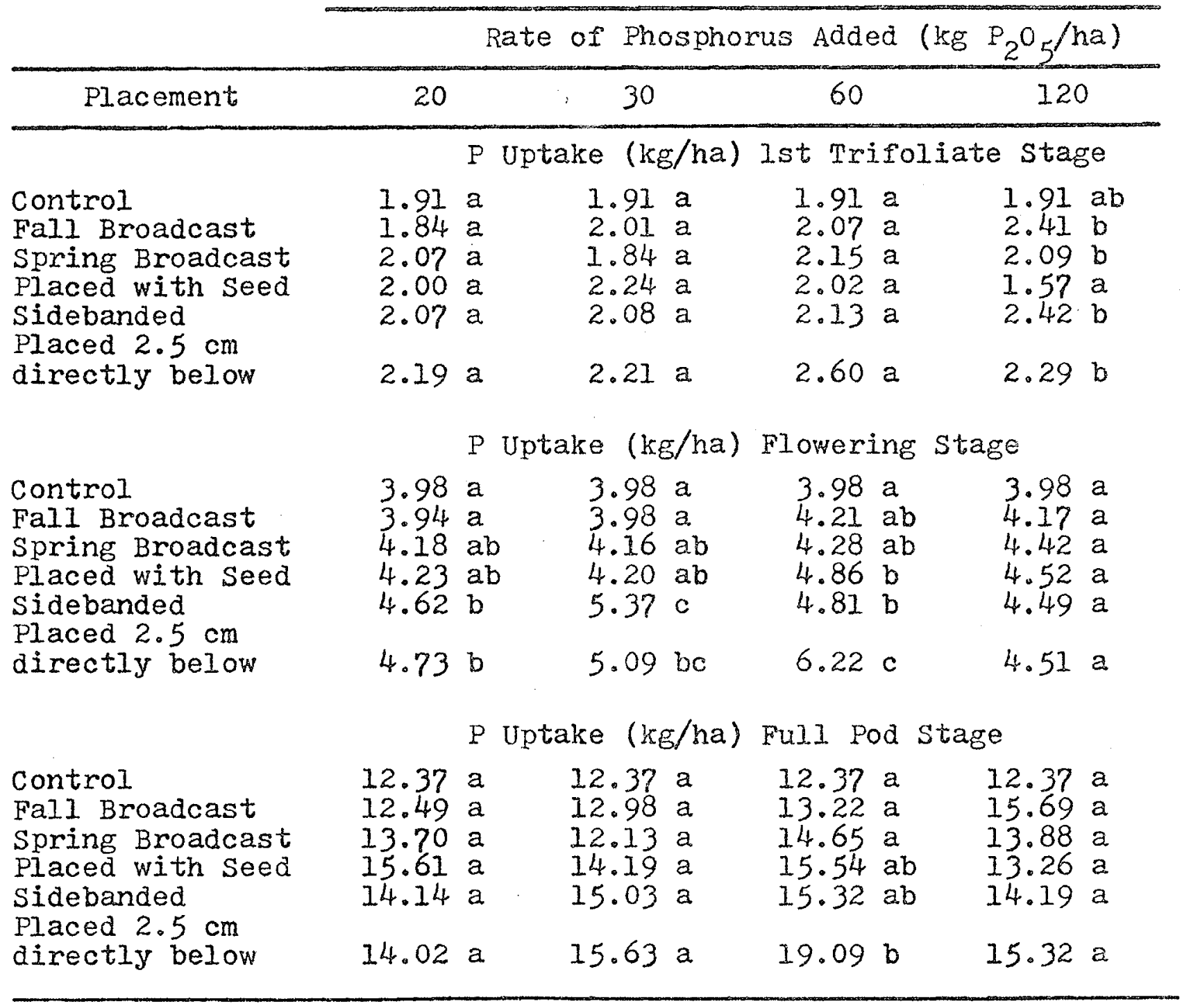

Duncan's Multiple Range Test: Numbers followed by the same letter are not significantly different at the 5\% level. Separate analyses done for each rate used. 
rates of fertilization at the first trifoliate stage. In most cases uptake of $\mathrm{P}$ with sidebanding was comparable to that with placement below but even where the differences were not significant uptake with the latter placement method was always superior.

Several authors have noted that seed-placed $P$ fertilizer can be advantageous in terms of early uptake faciliated by positional availability of the nutrient. (Sherrell et al 1964, Clapp and Small, 1970, Hoeft et al 1975, Sadler 1979). The results here show that to some extent this placement method was advantageous over broadcast methods, with rates of up to $30 \mathrm{~kg} \mathrm{P}{ }_{2} \mathrm{O}_{5} / \mathrm{ha}$. However, sidebanding and placement below the seed row produced comparable or better results at all rates and stages of growth, at both sites. It is also noticeable that $P$ uptake from seed-placed treatments was reduced when the rate of fertilization exceeded $30 \mathrm{~kg} \mathrm{P}_{2} \mathrm{O}_{5} / \mathrm{ha}$. This effect is quite distinct from the reduced seedling emergence earlier attributed to this placement method and may have reflected other injurious effects of this type of fertilization.

Table 25 and 26 give the total $P$ content in the grain and percentage $p$ in grain for soybean growth at the two sites. The results for total $P$ content follow trends similar to those observed with grain yield. This was not unexpected since the percentage $P$ content of grain at the two sites showed very Iittle variation with $P$ placement and rate of application. 


\section{TABLE 25}

TOTAL PHOSPHORUS IN SOYBEAN GRAIN AS AFFECTED BY RATE AND FLACENENT OF PHOSPHORUS FERTILIZER - FIEUD STUDY

A\& Brandon Site

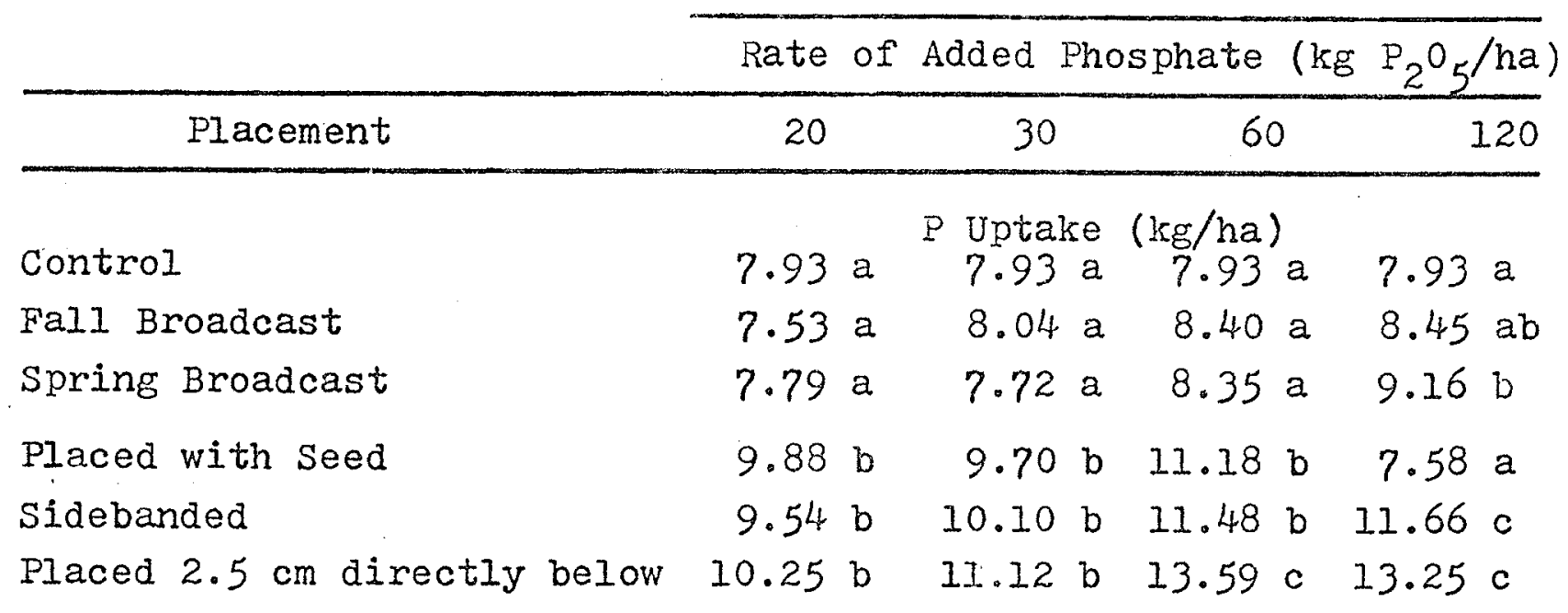

B: Neepawa Site

Control

Fall Broadcast

Spring Broadcast

Placed with seed

Sidebanded

Placed $2.5 \mathrm{~cm}$ directly below

\section{$P$ Uptake ( $\mathrm{kg} / \mathrm{ha})$}

7.11 a 7.11 a 7.11 a 7.11 a 7.93 a $\quad 7.83$ a 7.65 a $8.65 a b$ $8.06 \mathrm{ab} \quad 7.79$ a 7.71 a 8.55 a 8.75 bc 9.20 b 9.79 b 8.51 a 8.77 bc 9.98 b 10.09 b 10.07 b 9.52 c $\quad 9.82$ b $\quad 12.46$ c $\quad 11.50$ b

Duncan's Multiple Range Test: Numbers followed by the same letter are not significantly different at the $5 \%$ level. Separate analyses done for each rate used. 
TABLE 26

PERCENTAGE P IN SOYBEAN GRAIN AS AFFECTED BY RATE

AND PLACEMEIN OF PHOS PHO 2US FEZTIIIZER - PIELD STUDY

A: Brandon Site

\begin{tabular}{lcccc} 
& \multicolumn{1}{c}{ RATE OF ADDED PHOSPHATE $\left(\mathrm{kg} \cdot \mathrm{P}_{2} \mathrm{O}_{5} / \mathrm{ha}\right)$} \\
\hline \multicolumn{1}{c}{ Placement } & 20 & 30 & 60 & 120 \\
\hline Control & \multicolumn{4}{c}{$\% \mathrm{P}$} \\
Fall Broadcast & 0.68 & 0.68 & 0.68 & 0.68 \\
Spring Broadcast & 0.72 & 0.71 & 0.73 & 0.70 \\
Placed with Seed & 0.73 & 0.70 & 0.71 & 0.74 \\
Sidebanded & 0.73 & 0.69 & 0.73 & 0.69 \\
Placed 2.5 cm directly below & 0.68 & 0.69 & 0.71 & 0.70 \\
& 0.68 & 0.71 & 0.72 & 0.76
\end{tabular}

B: Neepawa Site

Control

Fall Broadcast

Spring Broadcast

Placed with Seed

Sidebanded

Placed $2.5 \mathrm{~cm}$ directly below
0.54

0.59

0.61

0.59

0.57

0.59
0.54

0.57

0.58

0.58

0.61

0.56
0.54

0.56

0.55

0.62

0.55

0.63
0.54

0.61

0.59

0.59

0.56

0.60 
The average total $P$ contents at the two sites were $9.44 \mathrm{~kg} / \mathrm{ha}$ at Brandon and $8.79 \mathrm{~kg} / \mathrm{ha}$ at Neepawa. These figures are low compared with the findings of Hanway and Weber (1971, II). In a three-year study with a number of nodulating and nonnodulating soybeans, they found that average $P$ accumulated in the seeds ranged from 10.8 to $20.5 \mathrm{~kg} / \mathrm{ha}$. It should however be stated that the grain yields from this experiment were relatively low compared with other studies and yields obtained in commerical practice.

Percentage $P$ in grain here averaged 0.71 at Brandon and 0.58 at Neepawa. dellooy et al (1973) quoted data from Borst and Thatcher (1931) which placed percentage $P$ for dried soybean seed at $0.65 \%$. Hanway and weber (1971. III) found that the average for several varieties of soybean was $0.60 \%$ P. Although the plants at Brandon accumulated greater amounts of seed phosphorus, seed yields were lower, than at Neepawa. The difference noted here may have been due to greater amounts of phosphorus being translocated into the seed at the Brandon plots, since at pod-fill, plants at both sites had accumulated similar amounts of total $P$. The grain from this experiment was also analysed for nitrogen content. The results were used to compute protein content of the grain using a multiplication factor of 6.25. Protein levels constitute an important parameter by which soybean cultivars are rated and recommended for commercial use. Average protein 


\section{PABLE 27}

INFLUENCE OF RATE AND PLACEMENT OF PHOS PHORUS FEXTILIZER ON PROTEIN CONTENT OF FIEID GROWN SOYBEANS

Site I: Brandon

\begin{tabular}{|c|c|c|c|c|}
\hline & \multirow{2}{*}{\multicolumn{4}{|c|}{ Rate of Added Phosphate $\left(\mathrm{kg} \mathrm{P}_{2} \mathrm{O}_{5} / \mathrm{l}\right.$}} \\
\hline & & & & \\
\hline Placement & 20 & 20 & 60 & 120 \\
\hline & \multicolumn{4}{|c|}{$\%$ Protein } \\
\hline Control & 33.96 & 33.96 & 33.96 & 33.96 \\
\hline Fall Broadcast & 35.21 & 32.94 & 32.21 & 33.93 \\
\hline Spring Broadcast & 33.08 & 33.75 & 33.50 & 32.27 \\
\hline Placed with Seed & 33.40 & 35.02 & 33.46 & 33.19 \\
\hline Sidebanded & 34.08 & 33.83 & 35.35 & 33.69 \\
\hline Placed $2.5 \mathrm{~cm}$ directly below & 35.02 & 33.88 & 32.98 & 33.13 \\
\hline \multicolumn{5}{|c|}{ Neepawa } \\
\hline Control & 38.66 & 38.66 & 38.66 & 38.66 \\
\hline Fall Broadcast & 37.56 & 37.75 & 38.44 & 35.17 \\
\hline Spring Broadcast & 36.46 & 38.86 & 37.46 & 36.86 \\
\hline Placed with seed & 36.56 & 37.27 & 36.96 & 36.52 \\
\hline Sidebanded & 37.44 & 36.88 & 37.34 & 38.02 \\
\hline Placed $2.5 \mathrm{~cm}$ directly below & 37.15 & 36.46 & 36.27 & 36.75 \\
\hline
\end{tabular}


levels at Neepawa $(37.37 \%)$ were slightly higher than at Brandon (33.74\%) as shown in Table 27. The figures however, showed no direct.relation to the applied treatments. Thus placement and rate of applied $P$ did not measurably affect protein content of soybean grain in this study.

Compared with protein levels found acceptable for commercial processing, the percentages found here are relatively low. Most processing units require grain with at least $40 \%$ protein (on a dry-weight basis) for efficient production of soybean meal and other by-products. Regitnig (1979. Unpublished) found that similar levels of protein were obtained with Maple Presto soybeans even when large amounts of nitrogen were added. This seemingly unfavourable characteristic of this cultivar, requires further investigation.

\section{Rate Study}

This experiment was undertaken with a view of finding an acceptable rate of phosphorus fertilization which would be applicable to the Maple Presto variety. Three sites were chosen, each with similar soil texture (Fine Sandy Loam). Soil levels of phosphorus ranged from $17.15 \mathrm{~kg} \mathrm{P} / \mathrm{ha}$ to 29.66 $\mathrm{kg} \mathrm{P} /$ ha, $\mathrm{NaHCO}_{3}$ extractable $\mathrm{P}$. Fertilization rates used were 0,30 and $100 \mathrm{~kg} \mathrm{P}_{2} \mathrm{O}_{5} /$ ha. Results of the grain yields obtained from this study are reported in Table 28 ,

The results show no significant yield increases due to 
TABLE 28

GRAIN YIELDS OF SOYBEANS GRONN AT THREE

SOUTHERN MANITOBA SITES, AS AFEECTED

BY. RATE OF PHOSPHORUS FERTILIZATION

\begin{tabular}{c|c|c|c|c}
\hline Fertilizer Treatment & \multicolumn{4}{|c}{ Sites } \\
\hline & & Toews & Nikkel & Enns \\
\cline { 2 - 4 } & & $\mathrm{kg} / \mathrm{ha}$ & \\
Control & 1925 a & 1439 a & $1620 \mathrm{a}$ \\
$\mathrm{P}_{1}$ & 1739 & $\mathrm{a}$ & 1495 a & $1786 \mathrm{a}$ \\
$\mathrm{P}_{2}$ & 1750 & $\mathrm{a}$ & 1501 a & $1796 \mathrm{a}$ \\
\hline
\end{tabular}

Duncan's Multiple Range Test: Numbers followed by the same letter are not significantly different at the 5\% level. Separate analyses done for each site.

Note: Control
\[ \begin{aligned} \mathrm{P}_{1} & =30 \mathrm{~kg} \mathrm{P} \mathrm{P}_{5} / \mathrm{ha} \\ \mathrm{P}_{2} & =100 \mathrm{~kg} \mathrm{P} \mathrm{P}_{5} \mathrm{O}_{5} / \mathrm{ha}\end{aligned} \]


P fertilization at any of the sites. In fact seed yields were actually reduced by $P$ fertilization at Toews on a soil which had a test level of $27.69 \mathrm{~kg} \mathrm{P} / \mathrm{ha}$. Even though yields from some of the fertilized plots reached as high as $2039 \mathrm{~kg} / \mathrm{ha}$, average yields were generally low and responses to $P$ fertilization absent.

Two features of this experiment should be noted: (I) thosphorus was banded at $5 \mathrm{~cm}$ away from the seed row and $5 \mathrm{~cm}$ below the seed level, and (2) the soils may be considered to be of medium $P$ fertility. Experience has shown that responses to $P$ fertilization are usually better on soils with low $P$ fertility. (Krantz et al 1949). The results of the second growth chamber study reported earlier indicated that sidebanding $P$ as described here, resulted in less favourable responses than with other methods of placement. The results, nevertheless, underline the uncertainly of soybean response to phosphorus fertilization. 


\section{CHAPTER V}

\section{SUMMARY AND CONCLUSIONS}

Two growth chamber and two field experiments were undertaken with the following objectives:-

1. To determine the pattern of phosphorus uptake and response by soybean (cultivar Maple Presto) when phosphorus fertilizer was applied in varying amounts to differently sized bands of soil.

2. To evaluate the effectiveness of various placement methods for phosphorus in terms of soybean response.

3. To compare various rates of phosphorus application for soybean planted on soils varying in soil available phosphorus.

The two growth chamber studies were conducted using soil low in available $\mathrm{P}$ (4.6 ppm $\mathrm{P}-\mathrm{NaHCO}_{3}$ extractable) which was obtained from the Portage la Prairie area. In the first study, five differently sized bands of so il representing 100\%, 50\%, $25 \%, 12.5 \%$ and $1 \%$ of the total soil volume were each treated with $0.1 \mathrm{gm}$ and $0.4 \mathrm{gm} \mathrm{P}$, applied in solution as $\mathrm{Ca}\left(\mathrm{H}_{2} \mathrm{PO}_{4}\right)_{2} \cdot 2 \mathrm{H}_{2} \mathrm{O}$. The experiment was allowed to run for 44 days i.e. up to midflowering, after which, dry matter yields, total $P$ uptake and $P$ derived from fertilizer were determined. In the second experiment, $0.2 \mathrm{gm}$ and $0.4 \mathrm{gm} \mathrm{P}$ as $\mathrm{Ca}\left(\mathrm{H}_{2} \mathrm{PO}_{4}\right)_{2} \cdot 2 \mathrm{H}_{2} \mathrm{O}$, were again applied in solution to the soil. $P$ applications were either banded in one of six locations below seed level or else $P$ was applied to $1 \%$ of the soil volume and this was spread as a wide 
band below the seed. In both experiments, $P$ fertilizer was tagged with $32_{P}$ in order to determine $P$ uptake from the fertilizer.

The first field experiment was conducted at two sites, each with soils low in available phosphorus $-4.8 \mathrm{~kg} P / \mathrm{ha}$ at Brandon and $4.3 \mathrm{~kg} \mathrm{P} /$ ha at Neepawa ( $\mathrm{NaHCO}_{3}$ extractable). This study compared five placement methods for phosphorus fertilizer:(a) Fall Broadcast and worked in (b) Spring Broadcast and worked in (c) Placement in contact with the seed (d) Sidebanding $2.5 \mathrm{~cm}$ below and $2.5 \mathrm{~cm}$ away from the seed (e) Placement at $2.5 \mathrm{~cm}$ directly below the seed. P was applied as 0 46 - 0 at rates of $20,30,60$ and $120 \mathrm{~kg} \mathrm{P}_{2} \mathrm{O}_{5} / \mathrm{ha}$. Harvests were taken at three stages during growth and at maturity. Grain yields as well as dry matter production at the various growth stages were determined. Straw and grain samples were analysed for $P$ content and to determine total $P$ uptake at each stage. Grain samples were also analysed for $\mathrm{N}$ content which was used to evaluate protein content of the grain.

The second field study compared two rates of $P$ application for soybean at three sites. Phosphorus as $\mathrm{Ca}\left(\mathrm{H}_{2} \mathrm{PO}_{4}\right)_{2} \cdot 2 \mathrm{H}_{2} \mathrm{O}$ was sidebanded $5 \mathrm{~cm}$ below and $5 \mathrm{~cm}$ away from the seed at 30 and $100 \mathrm{~kg} P_{2} 0_{5} / \mathrm{ha}$. The soils here, had test levels of 17.15 , 27.69 and $29.66 \mathrm{~kg} \mathrm{P}_{2} \mathrm{O}_{5} / \mathrm{ha}$ ( $\mathrm{NaHCO}_{3}$ extractable). Grain yield was used as the parameter for comparing soybean response to these treatments. 
Under the conditions of the investigation, the following conclusions were drawn:-

1. In both growth chamber experiments, soybean responded well to phosphorus fertilizer applied on low-P soil.

2. Dry matter yield, total phosphorus uptake and phosphorus derived from the fertilizer all increased as the size of the phosphated band (of soil) was decreased in the first growth chamber study. It was concluded that chemical availability of applied $P$ increased as the zone of fertilizer reaction was made smaller. Absorption studies conducted on the soil also showed that $P$ availability as measured by $\% \mathrm{P}$ remaining in solution, increased as greater amounts of fertilizer $P$ were added to the soil.

3. Absorption of soil phosphorus by soybean plants in the first growth chamber experiment, increased with plant size up to a dry weight of approximately $28 \mathrm{gm}$. "A" values increased with the amount of $\mathrm{P}$ added and decreased with the decrease in the size of the treated band. It was concluded that the potentially available soil phosphorus increased as the plant roots extended to explore the soil phosphorus reservoir.

4. In the second growth chamber experiment soybean responded differently to phosphorus banded in six locations below the seed. Placement of the fertilizer $2.5 \mathrm{~cm}$ directly below the seed was most effective in increasing dry matter yield, total phosphorus uptake and utilization of fertilizer P. It was concluded that better positional availability of the fertilizer 
placed in this location was partly responsible for the responses observed.

5. Placement of phosphorus was also of critical importance to soybean response to added $P$ in the first field study. Grain yields were highest at both sites, when $P$ was placed $2.5 \mathrm{~cm}$ directly below the seed at $60 \mathrm{~kg} \mathrm{P}_{2} \mathrm{O}_{5} / \mathrm{ha}$. Sidebanding $\mathrm{P} 2.5$ $\mathrm{cm}$ below and $2.5 \mathrm{~cm}$ away from the seed was not as effective in increasing grain yield but was superior to seed placement and broadcast applications, at all rates of $P$ application and at both sites. Broadcasting $\mathrm{P}$ in Fall or in spring at rates of up to $120 \mathrm{~kg} \mathrm{P} \mathrm{O}_{5} / \mathrm{ha}$ did not result in significantly higher grain yielas than those achieved in the control plots. P placement $2.5 \mathrm{~cm}$ directly below the seed at $20 \mathrm{~kg} \mathrm{P}_{2} \mathrm{O}_{5} /$ ha resulted in higher grain yields, at both sites, than were obtained with broadcast applications of $120 \mathrm{~kg} \mathrm{P}_{2} \mathrm{O}_{5} / \mathrm{ha}$.

6. Dry matter yields and total phosphorus uptake in the first field experiment were significantly increased at the flowering and full-pod stages, by placement of $P 2.5 \mathrm{~cm}$ directly below the seed. These responses were again attributed partly to better positional availability of fertilizer $P$ placed in this manner. At both sites, placement of $P$ in contact with the seed appeared to result in reduced seedling emergence (which was reflected in reduced dry matter yields) when rates of $120 \mathrm{~kg} \mathrm{P} \mathrm{O}_{5} /$ ha were used. Total phosphorus uptake with this treatment was also reduced at both sites. 
7. No significant yield responses to phosphate fertilization were obtained in the second field experiment. While the results underline the uncertainty of soybean response to $P$ fertilization, two factors were thought to be responsible:(a) Soil P levels at the three sites were much higher than in the other field experiment and (b) $P$ was banded $5 \mathrm{~cm}$ below and $5 \mathrm{~cm}$ away from the seed. This placement method was shown to be less effective than other methods used in the second growth chamber study. 


\section{BIBLIOGRAPHY}

Alexander, Martin. 1977. Nitrogen Fixation: Symbiotic. Chapter 19 in Introduction to Soil Microbiology 2nd Edition. Published by John Wiley and Sons.

Arnon, D.I. 1953. The physiology and biochemistry of phosphorus in green plants. Chapter I in Soil and Fertilizer Phosphorus. Volume IV in a Series of Monographs on Agronomy. A.S.A. Publication.

Bailey, L.D. 1967. The effect of various fertilizer treat ments on the yield of flax and barley. Annual Manitoba Soil Science Meeting; University of Manitoba, Winnipeg. Manitoba. pp. $109-117$.

Bailey, I. D., H. Ukraninetz, and D.R. Walker. 1980. Effect of Phosphorus Placement on Crop Uptake and Yield. Western Canada Phosphate Symposium. pp. $200-220$.

Bates, T.E. 1971. Response of Com to Small Amounts of Fertilizer Placed with the Seed: II Summary of 22 Field Trials. Agronomy Journal, Volume 63: $369-371$.

Bates, T.E. 1971. Response of corn to Small Amounts of Fertilizer Placed with the Seed: III Relation to $P$ and $\mathrm{K}$ Placement and Tillage. Agronomy Joumal, Volume 63: $372-375$.

Bhangoo, M.S. and D.J. Albritton. 1972. Effect of Fertilizer Nitrogen. Phosphorus and Potassium on Yield and Nutrient Content of Lee Soybeans. Agronomy Journal, Volume 64: $743-746$.

Boswell. Fred, C. and D.E. Anderson. 1975. Long-term Residual Fertility and Current $\mathrm{N}-\mathrm{P}-\mathrm{K}$ Application Effects on Soybeans. Agronomy Journal, Volume 68: 315 - 318.

Bray, Roger, H. 1954. A Nutrient Mobility Concept of Soil Plant Relationships. Soil Science, Volume 78, $9-22$.

Burea u, Marvin, F.. Henry J. Mederski and C.E. Evans. 1953. The Effect of Phosphatic Fertilizer Material and Soil Phosphorus Level on the Yield and Phosphorus Uptake of Soybeans. Agronomy Journal, Volume 45: $150=154$.

Buzzell, R.I., L.S. Donovan, and J.E. Giesbrecht. 1972, Grow ing Soybeans. Publication No. 1487. Agriculture Canada.

Camper, H.M. and J.A. Lutz, Jr. 1977. Plowsole Placement of 
Fertilizer for Soybeans and Response to Tillage of Plowsole. Agronomy Joumal, Volume 69: 701 - 704.

Chesney, H.A.D. 1973. Performance of Soybeans (Glycine max

(I) Merrili) in the Wet Tropics as Affected by $N_{A} P$ and

$\mathrm{K}$. Agronomy Journal, Volume 65:887 - 889.

Cihacek, L.J., D.I. Mulvaney, R.A. OIson, I.F. WeIch, and R.A. Wiese. 1974. Phosphate Placement for Corn in Chisel and Moldboard Plowing Systems. Agronomy Joumal, Volume 66: 665 - 668 .

Clapp, J.A. Jr. and H.G. Small, Jr. 1970. Influence of "Popup" Fertilizers on Soybean Stands and Yield. Agronomy Joumal, Volume 62: $802-803$.

dellooy, C.J. and John Pesek. 1966. Nodulation Response of Soybeans to Added Phosphorus, Potassium and Calcium Salts. Agronomy Journal, Volume 58:275 - 280.

deMooy, C.J. and John Pesek. 1970. Differential Effects of $P, K$ and Ca Salts on Leaf Composition, Yield and Seed Size of Soybean Iines. Crop Science, Volume 10: $72-77$.

dellooy, C.J.. J. Pesek and E. Spaldon. 1976. Mineral Nutrition: Chapter 9 in Soybeans: Improvement. Production and Uses. No. 16 in the Series, Agronomy. A S A Publication.

dellooy C.J.. J.I. Young and J.D. Kaap. 1973. Comparative Response of Soybeans and Corn to Phosphorus and Potassium. Agronomy Journal, Volume 65: 851 - 855.

Edwards, J.H. and S.A. Barber. 1976. Phosphorus Uptake Rate of Soybean Roots as Influenced by Plant Age, Root Trimming and Solution $P$ Concentration. Agronomy Journal, Volume 68: 973 - 975 .

Fletcher, H.F. and I.T. Kurtz. 1964. Differential Effects of Phosphorus Fertility on Soybean Varieties. Soil Science Society and America Proceedings, Volume 62: 226 - 228.

Fried, No and H. Broeshart. 1967. Determination of Soil Nutrient Supply: Chapter 6 in The Soil-Plant System. Published by Academic Press.

Gates, C.T. and W.J. Muller. 1979. Nodule and Plant Development in the Soybean, Glycine $\max$ (L) Merr.: Growth Response to Nitrogen, phosphorus and Sulfur. Australian Journal of Botany, Volume 27: $203-215$.

Ham, G.E.,W.W. Nelson, S.D. Evans, and R.D. Frazier. 1973. Influence of Fertilizer Placement of Yield Response of Soybeans. Agronomy Journal, Volume 65: 81 - 84. 
Ham G.E. and A.C. Caldwell. 1978. Fertilizer Placemęnt Effects on Soybean Seed Yield, $\mathrm{N}_{2}$ Fixation and ${ }_{\mathrm{P}}$ Uptake. Agronomy Journal, Volume $70: 779^{2}-783$.

Hanson, R.G. 1979. Effect Upon Soybean Cultivar Bragg, When $P$ is Band-Concentrated Upon Variable Soil-Available $P$. Agronomy Joumal Volume 71: 267 - 271 .

Hanway, J.J. and C.R. Weber, 1971. I Dry Matter Accumulation in Soybean (Glycine max (I) Merrill) Plants as Influenced by $N, P$ and $\mathrm{K}$ Fertilization. Agronomy Joumal. Volume 63: $263-266$.

Hanway, J.J. and C.R. Weber. 1971. II N, P and K Percentages in soybean (Giycine max (I) Merrili) Plant Parts. Agronomy Journal, Volume 63: $286-290$.

Hanway, J.J. and C.R. Weber. 1971. III Accumulation of N, P, and $\mathrm{K}$ by Soybean (Glycine max (I) Merrill) Plants. Agronomy Journal, Volume $63: 406-408$.

Harper, James, E. 1971. Seasonal Nutrient Uptake and Accumulation Patterns in Soybeans. Crop Science, Volume 11: $347-350$.

Hoeft, R.G.. I.M. Walsh and E.A. Iiegel. 1975. Effect of SeedPlaced Fertilizer on the Emergence. (Germination) of Soybeans (GIycine Max $\left.I_{.}\right)$and Snapbeans (Phaseolus vulgaris I). Communications in Soil science and Plant Analysis. Volume $6(6): 655-664$.

Howell, Robert, W. 1954. Phosphorus Nutrition of Soybeans. Plant Physiology. Volume 29: 477 - 482 .

Howell, Robert, W. and Richard I. Bermard. 1961. Phosphorus Response of Soybean Varieties. Crop Science, Volume 1: 311 - 313.

Islam, A. 1964. The Yield and Chemical Composition of Soybeans as affected by three levels of Complementary Nutrients Associated with five levels of Phosphorus. Pakistan Joumal of Soil Science, Volume 1: $32-49$.

Jamison, V.C. and J.F. Thornton. 1960. Results of Deep Fertilization and Subsoiling on a Claypan Soil. Agronomy Journal 52: 193 - 195 .

Kalra, Y.P. 1971. Different behaviour of crop species in phosphate absorption. Short Communication in Plant and Soil, Volume 34:535, 539. 
Kalra, Y.P. and R.J. Soper. 1968. Efficiency of Rape, Oats, Soybeans, and Flax in absorbing Soil and Fertilizer Phosphorus at Seven Stages of Growth. Agronomy Journal, Volume 60: $209-212$.

Kalra, Y.P. 1966. A Comparative Study of Phosphorus Uptake by Several Field Crops. M.Sc Thesis, University of Manitoba.

Kamprath, E.J. and E.V. Miller. 1958. Soybean Yields as a Function of the Soil Phosphorus Level. Soil Science Society of America Proceedings, Volume 22: 317 - 319.

Keogh, Joseph, I. and Richard Maples. 1970. Soybean FertiIization: Timing and Placement of Phosphoms and Potassium. Report Series 185. Agricultural Experiment Station, University of Arkansas.

Krantz, B.A., W.I. Nelson, C.D. Welch and N.S. Hall. 1949. A Comparison of Phosphorus Utilization by Crops. Soil Science, Volume 68: 171 - 177 .

Larson, W.E. W.G. Lovely, J.T. Pesek, and R.E. Burwell. 1960. Effect of Subsoiling and Deep Fertilizer Placement on Yields of Com in Iowa and Iilinois. Journal. Volume 52: $185-189$.

Lee, K.W.. A.C. Caldwell, and C.E. Clapp. 1966. RNA, DNA and other Phosphorus Fractions in Soybeans as Affected by High Phosphorus Nutrition. Plant and Soil XXV, No.3: $406-412$.

Lee, K.W., C.E. Clapp, and A.C. Caldwe11. 1976. Phosphorylated Compounds in Soybean (Glycine max (L) Merr.) as affected by Phosphorus levels in Solution. Short Cornm. in Plant and Soil $44: 475-479$.

Lewis, D.G. and J.P. Quirk. 1967.31Phosphate Diffusion in Soil and Uptake by Plants. IJI P 31 Movement and Uptake by Plants as Indicated by $\mathrm{P}^{32}$ Autoradiography. Plant and Soil XXVII, No. \#: $445-452$.

Lutz, J.A. Jr., G.I. Terman, and J.I. Anthony. 196I. Rate and Placement of Phosphorus for Small Grains. Agronomy Journal, Volume 53: 303 - 305.

Miller, M.H., T.E. Bates, D. Singh, and A.S. Baweja. 1971. Response of Corn to Small amounts of Fertilizer Placed with the Seed: I Greenhouse studies. Agronomy Joumal volume 63: $365-368$. 
Miller, R.J.. J.T. Pesek, and J.J.Hanway. 1961. Relationships between Soybean Yield and Concentrations of Phosphorus and Potassium in Plant Parts. Agronomy Journal, Volume 53: $393-396$.

Moore, A.W., E.M. Brouse, and H.F. Rhoades. 1968. Influence of Phosphorus Fertilizer Placement on two Nebraska Sub Irrigated Meadows. Journal of Range Management, Volume 21: $112-114$.

Nyborg, Marvin and A.M.F. Hennig. 1969. Field Experiments with Different Placements of Fertilizers for Barley, Flax and Rapeseed. Canadian Journal of Soil Science. Volume 49: $79-88$.

Nye, P.H. 1968. Processes in the Root Environment. Journal of Soil Science, Volume 19, No.2: $205-215$.

Ohlrogge, A.J. 1960. Mineral Nutrition of Soybeans. Advances in Agronomy, volume 12: $229-263$.

Olsen, S.R., F.S. Watanabe, and R.E. Danielson. 1961. Phosphomus Absorption by Corn Roots as Affected by Moisture and Phosphorus Concentration. Soil Science Society of America Proceedings, Volume 25: 289 - 294.

Olson, R.A. and A.F. Dreier. 1956. Fertilizer Placement for Small Grains in Relation to Crop stand and Nutrient Efficiency in Nebraska. Soil Science Society of America Proceedings, Volume 20: $19-24$.

Peaslee, D.E. 1978. Relationshlps Between Relative Crop Yields, Soil Test Phosphorus Levels, and Fertilizer Requirements for Phosphorus. Communications in Soil Science and Plant Analysis, Volume 9(5): $429-442$.

Peevy, W.J., B.E. Newman, J.E. Sedberry, Jr. and R.H. Brupbactier. 1972. The influence of Soil Reaction, Residual Soil Phosphorus and Fertilizer Phosphorus on the Yield of Soybeans grown on Olivier Silt Loam. Lousiana Experimental Station, Bulletin. No. 669: $2-20$.

Racz, G.J., M.D. Webber, R.J. Soper, and R.A. Hedlin. 1965. Phosphorus and Nitrogen Utilization by Rape, Flax and Wheat. Agronomy Journal, Volume 57: $335-337$.

Regitnig. P. 1979. The effects of Nitrogen Fertilization on Symbiotic Nitrogen Fixation. Yield and Protein content in Soybeans and Blackbeans. Unpublished data. 
Robertson, J.A., B.T. Kang, F. Ramirez-Paz, C.H.E. Werkhoven, and A.J. Ohlrogge. 1966. Pringiples of Nutrient Uptake from Fertilizer Bands. VII. P32 Uptake by Brace Roots of Maize and its Distribution within the Leaves. Agronomy Journal, Volume 58: $293-296$.

Sadler, J.M. 1979. Effect of Different Placements of Phosphorus Banded Away From the seed on Growth and Uptake of Soil and Fertilizer Phosphorus by Flax. Mimmeograph Data. Sent to Press.

Sheard, R.W.. G.J. Bradshaw, and D. Lawrence Massey. 1971. Phosphorus Placement for the Establishment of Alfalfa and Bromegrass. Agronomy Joumal. Volume 63: $922-927$.

Sherrell C.G.. J.W. Ketcheson, and M.H. Miller. 1964. The Effect of Placement of Banded Fertilizer on Fertilizer Phosphorus Absorption and Yield of oats in Greenhouse and Field Experiments. Canadian Joumal of Soil Science, Volume $44,329-336$.

Strong, W.M. and R.J. Soper. 1974. Phosphorus Utilization by Flax, Wheat, Rape and Buckwheat from a Band or Pelletlike Application. I. Reaction Zone Root Proliferation. Agronomy Soumal, Volume 66: 597 - 601 .

Strong. W.M. and R.J. Soper. 1974. Phosphorus Utilization by Flax, Wheat, Rape and Buckwheat from a Band or Pelletlike Application. II. Influence of Reaction Zone Phosphorus Concentration and Soil Phosphorus Supply. Agronomy Joumal, Volume 66: 60: -605 .

Thomas, G.W. and D.E. Peaslee 1973. Testing Soils for Phosphorus. Chapter 9 in Soil Testing and Plant Analysis. Soil Science of America Publication.

Terman, G.I., J.D. Dellent, and O.P. Englestad. 1961. Crop Response to Fertilizers Varying in Solubility of the Phosphorus, as Affected by Rate, Placement and Seasonal Environment. Agronomy Joumal, Volume 53: $221-224$.

Webber, M.D. 1963. The Phosphorus Feeding Habits of Flax, Cereals and Rape. MSc Thesis, University of Manitoba.

Welch, C.D., N.S. Hall and W.I. Nelson. 1949. Utilization of Fertilizer and Soil Phosphorus by Soybeans. Soil Science of America Proceedings, Volume 14: $231=235$.

Woodhouse, W.W. Jr. 1956. Effect of Placement and Rate of Phosphorus, Potash and Iimestone on the Growth of Alfalfa and Lespedeza. Soil Science Society of America Proceedings, Volume 20: $15-18$. 